\title{
Crustal reworking and hydration: insights from element zoning and oxygen isotopes of garnet in high-pressure rocks (Sesia Zone, Western Alps)
}

\author{
Vho Alice $^{1}(\mathbb{D}) \cdot$ Rubatto Daniela $^{1,2} \mathbb{D} \cdot$ Lanari Pierre $^{1}\left(\mathbb{D} \cdot\right.$ Giuntoli Francesco $^{3}\left(\mathbb{D} \cdot\right.$ Regis Daniele $^{4} \cdot$ Hermann Jörg $^{1}(\mathbb{D}$
}

Received: 9 June 2020 / Accepted: 7 October 2020 / Published online: 30 October 2020

(c) The Author(s) 2020

\begin{abstract}
Subduction zones represent one of the most critical settings for fluid recycling as a consequence of dehydration of the subducting lithosphere. A better understanding of fluid flows within and out of the subducting slab is fundamental to unravel the role of fluids during burial. In this study, major and trace element geochemistry combined with oxygen isotopes were used to investigate metasediments and eclogites from the Sesia Zone in order to reconstruct the effect of internal and external fluid pulses in a subducted continental margin. Garnet shows a variety of textures requiring dissolution-precipitation processes in presence of fluids. In polycyclic metasediments, garnet preserves a partly resorbed core, related to pre-Alpine high-temperature/low-pressure metamorphism, and one or multiple rim generations, associated with Alpine subduction metamorphism. In eclogites, garnet chemical zoning indicates monocyclic growth with no shift in oxygen isotopes from core to rim. In metasediments, pre-Alpine garnet relics show $\delta^{18} \mathrm{O}$ values up to $5.3 \%$ higher than the Alpine rims, while no significant variation is observed among different Alpine garnet generations within each sample. This suggests that an extensive re-equilibration with an externally-derived fluid of distinct lower $\delta^{18} \mathrm{O}$ occurred before, or in correspondence to, the first Alpine garnet growth, while subsequent influxes of fluid had $\delta^{18} \mathrm{O}$ close to equilibrium. The observed shift in garnet $\delta^{18} \mathrm{O}$ is attributed to a possible combination of (1) interaction with sea-water derived fluids during pre-Alpine crustal extension and (2) fluids from dehydration reactions occurring during subduction of previously hydrated rocks, such as the serpentinised lithospheric mantle or hydrated portions of the basement.
\end{abstract}

Keywords Oxygen isotopes $\cdot$ Subduction $\cdot$ Garnet $\cdot$ Fluid $\cdot$ Sesia Zone

\section{Introduction}

Communicated by Steven Reddy.

Electronic supplementary material The online version of this article (https://doi.org/10.1007/s00410-020-01745-6) contains supplementary material, which is available to authorized users.

Vho Alice

alice.vho@geo.unibe.ch

1 Institute of Geological Sciences, University of Bern, Baltzerstrasse 1+3, Bern, Switzerland

2 Institut Des Sciences de La Terre, University of Lausanne, Lausanne, Switzerland

3 Department of Biological, Geological and Environmental Sciences, University of Bologna, Bologna, Italy

4 Geological Survey of Canada, Ottawa, ON, Canada
Aqueous fluids play a critical role during metamorphic processes in the Earth's crust and upper mantle acting as catalysts for chemical reactions, affecting stable mineral assemblages and controlling mineral textures and element distribution at the micro scale (e.g. Erambert and Austrheim 1993; Ague 2003; Parsons and Lee 2009; Putnis 2009; Beinlich et al. 2010; Jamtveit and Austrheim 2010; Putnis and Austrheim 2010). Metamorphic fluids generally escape the rock system with which they have reacted. However, they may leave behind distinctive geochemical and isotopic signatures in minerals that can assist in reconstructing their paths, sources and the exchange between different systems. During metamorphism, minerals nucleate, grow and re-equilibrate (via diffusion and/or dissolution-precipitation) as a response of changing pressure $(P)$, temperature $(T)$ and chemical conditions. Information about previous 
metamorphic stages can be partially recorded when reequilibration is incomplete, allowing metastable mineral relics and compositional growth zones to be preserved (e.g. Lanari and Engi 2017). As fluid-rock interaction can occur during several events separated in time and under different physicochemical conditions, an approach that combines field observations, petrological and geochemical characterization of key metamorphic minerals and geochronology constitutes the basis for determining $P-T$-time-fluid paths (Martin et al. 2011, 2014a; Baxter et al. 2017; Rubatto and Angiboust 2015; Gerrits et al. 2019).

Subduction zones are critical settings on Earth for crustal recycling from the surface into the mantle (e.g. Poli and Schmidt 2002; Jarrard 2003; Hermann et al. 2013; Spandler and Pirard 2013). In these settings oceanic crust, sediments and lithospheric mantle, but also continental lithosphere, sink into the mantle and undergo significant metamorphism at sub-solidus conditions assisted by the presence of fluids. High-pressure (HP) fluids are generally aqueous solutions (Scambelluri and Philippot 2001; Manning 2004; Hermann et al. 2006), with variable amounts of carbon species (e.g. Piccoli et al. 2018; Vitale Brovarone et al. 2018). The subduction of continental slices to HP conditions is well documented, but little is known about the effects of interaction between these rock types and fluids during subduction (Engi et al. 2018). It has been suggested that subducted continental crust might be in many cases fluid-undersaturated (Hermann 2002). The relatively small amount of fluids in these lithologies with respect to oceanic crust requires a more targeted approach, such as in-situ microanalysis, to identify mineral zones that may have recorded significant fluid-rock interaction.

Garnet has been widely used in metamorphic petrology to retrieve $P-T$ paths as this common rock-forming mineral (1) is stable over a wide range of metamorphic conditions, (2) shows large variability in chemical composition reflecting changes in $P$ and $T$ (e.g. Spear 1995; Caddick and Kohn 2013), (3) can coexist with various mineral assemblages (e.g. Baxter et al. 2017) and (4) can preserve elemental zoning as a result of limited elemental diffusion processes at $T<600{ }^{\circ} \mathrm{C}$ (e.g. Chakraborty and Ganguly 1991; Spear 1995; Konrad-Schmolke et al. 2006). Garnet growth along a prograde path produces generally a bell-shaped minor and trace element chemical zoning controlled by Rayleigh-type fractionation (Otamendi et al. 2002; Moore et al. 2013), but complex metamorphic processes and fluid-rock interactions may lead to more irregular patterns (e.g. Spear and Kohn 1996; Schumacher et al. 1999; García-Casco et al. 2002; Konrad-Schmolke et al. 2007; Giuntoli et al. 2018b). While major cations in garnet can help reconstructing the $P-T$ evolution of a sample, they provide poor information about fluid-rock interaction. In this regard, oxygen isotope studies represent a fundamental contribution in the investigation of fluid sources and pathways. The capacity of measuring oxygen isotopes in garnet at the microscale using ion microprobes (Vielzeuf et al. 2005; Page et al. 2010; Martin et al. 2014a) has opened the possibility to observe sub-mineral scale isotopic zoning. In a system at equilibrium, the oxygen isotope composition of garnet depends on (1) the bulk rock oxygen isotope composition, (2) the temperature of crystallization and (3) the stable mineral assemblage (e.g. Baumgartner and Valley 2001). Hence, oxygen isotope studies require a profound petrological understanding of the investigated systems to shed light on thermal, chemical, fluidassisted and deformational processes occurring both at the sample scale and at the regional scale.

This study focuses on HP rocks from the Sesia Zone (Western Alps, Italy, Fig. 1), which represents a relatively large terrane composed of subducted continental crust. In the past decades, the tectonic and metamorphic evolution of this area has been extensively investigated, providing a well-constrained petrological context for the interpretation of oxygen isotope data. This complex metamorphic terrane allows investigation of the effects of fluid-rock interaction when a previously extended plate margin is involved in subduction. We conducted a petrological, mineralogical and geochemical analysis of various samples deriving from different structural positions. These samples show high degrees of partial re-equilibration of high-temperature (HT) assemblages at blueschist and/or eclogite facies conditions during the Alpine orogenic cycle. Our approach combines major and trace element zonation patterns in garnet with microscale in situ oxygen isotope compositions in order to gain insights into the $P-T$-fluid evolution of the Sesia Zone.

\section{Geological setting}

The Sesia Zone (SZ) is the largest exposed slice of Adriatic continental crust in the Western Alps (Fig. 1). It was part of the distal continental margin of the Adriatic plate and was separated from the European continental crust by the Piemonte-Liguria Ocean. The SZ consists of an elongate body with a NE-SW trend, a maximum width of $\sim 25 \mathrm{~km}$ and a length of $\sim 100 \mathrm{~km}$ (e.g. Compagnoni 1977). It is composed of a variety of metapelites, metagranitoids, mafic rocks, and subordinated ultramafic bodies and marbles (e.g. Piaz 1972; Compagnoni 1977; Giuntoli and Engi 2016; Regis et al. 2015). The pre-Permian evolution of the SZ basement is not well constrained. One of the oldest events dated are early Carboniferous gabbroic intrusions in the crystalline basement (Rubatto et al. 1999). Bimodal magmatism at the Carboniferous-Permian boundary is well established and was likely associated with amphibolite to granulite facies metamorphism (Oberhänsli et al. 1985; Lardeaux and Spalla 1991; Rubatto et al. 1999; Rebay and Spalla 2001; Zucali 


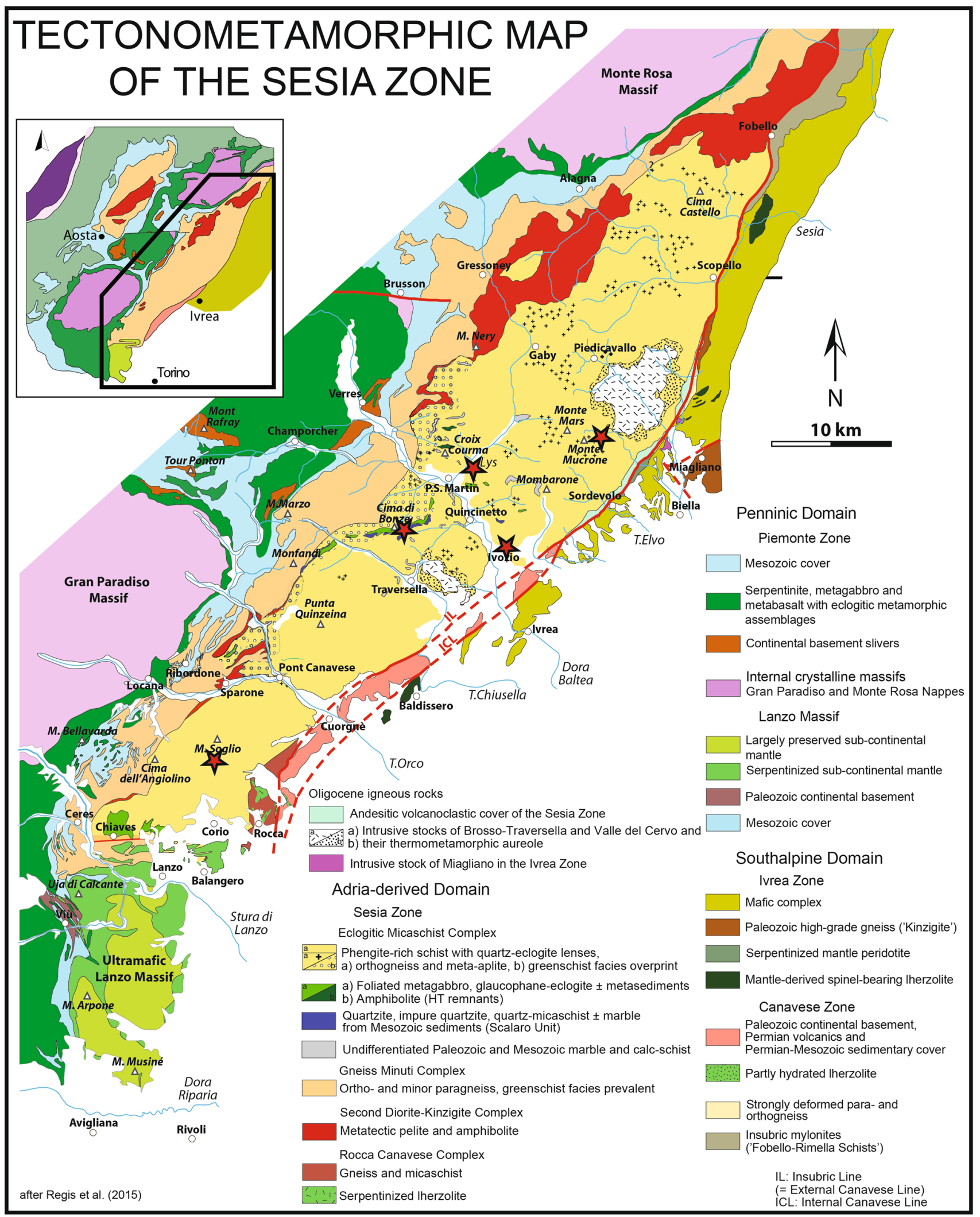

Fig. 1 Tectonometamorphic map of the Sesia Zone modified after Regis et al. (2015). The investigated localities are marked with red stars 
et al. 2002; Giuntoli et al. 2018a; Kunz et al. 2018). This basement underwent Alpine continental subduction testified by extensively preserved blueschist to eclogite facies assemblages, as already established by pioneering studies (e.g. Piaz 1972; Compagnoni 1977; Pognante et al. 1980; Lardeaux et al. 1982; Pognante 1989a, 1991). Greenschistfacies overprinting is related to the Alpine collisional stage.

The SZ has been traditionally divided into three subunits (Compagnoni 1977): (1) the Eclogitic Micaschist Complex (EMC), (2) the Gneiss Minuti Complex (GMC) and (3) the Second Dioritic-Kinzigitic Zone (IIDK) (Fig. 1). The EMC recorded maximum pressure of $2.0 \mathrm{GPa}$ and maximum temperature of $650-670{ }^{\circ} \mathrm{C}$, between $\sim 85$ and $55 \mathrm{Ma}$ (e.g. Compagnoni 1977; Gosso 1977; Pognante 1989b; Rubatto et al. 1999, 2011; Tropper and Essene 1999; Zucali et al. 2002; Konrad-Schmolke et al. 2006; Regis et al. 2014; Giuntoli et al. 2018b). The southern portion of the EMC was recognized to record lower peak conditions with respect to the central part $\left(P \sim 1.6 \mathrm{GPa}, T=500-550{ }^{\circ} \mathrm{C}\right.$, Pognante 1989a). In the EMC, the eclogite mineral assemblages are generally well preserved, with only local greenschist facies overprint. Alpine peak conditions for the GMC are lower at 1.1-1.2 GPa and $350-500{ }^{\circ} \mathrm{C}$ (e.g. Giuntoli et al. 2018b; Pognante $1989 \mathrm{a}, \mathrm{b}$ ) and the greenschist facies metamorphism is more pervasive. The IIDK consists of kilometric lenses of extensively preserved pre-Alpine amphibolites and granulites recording only local eclogite or blueschist facies re-equilibration (e.g. Lardeaux and Spalla 1991). This division has been partially revised by later studies (Venturini et al. 1994; Babist et al. 2006; Regis et al. 2014; Giuntoli and Engi 2016). Because we investigated different localities across the EMC (see below), we refer in the following to the traditional and more general subdivision proposed by Compagnoni (1977).

There is an open debate about the conditions and extension of hydration of the SZ after the pre-Alpine high temperature metamorphism. Episodic hydration of the EMC was proposed to occur (1) during exhumation accompanying rifting between the late Permian and the Jurassic (Rebay and Messiga 2007), (2) during the prograde subduction metamorphism (e.g. Zucali and Spalla 2011), (3) close to peak $P-T$ conditions (Engi et al. 2018; Giuntoli et al. 2018b) and (4) after the thermal peak (Pognante 1989b; KonradSchmolke et al. 2011a, b).

In order to have a regional cover of the complex evolution of the SZ, different areas located in the central and southern part of the EMC were investigated (SW to NE): (1) Malone Valley; (2) Ivozio Complex; (3) Chiusella Valley; (4) Lys Valley; and (5) Monte Mucrone (Fig. 1).

\section{Field relationships and sample description}

Metasediments, associated mafic boudins, and larger intrusive bodies were sampled along the southern and the central part of the EMC (Fig. 1, Online Resource 1). Since the main aim of this work is to better understand and constrain the pre-Alpine versus Alpine $P-T$-fluid evolution of the SZ, particular attention was paid to (1) the polycyclic metasediments, as they preserve pre-Alpine metamorphic relics (e.g. garnet and zircon cores; Giuntoli et al. 2018a, b; Kunz et al. 2018), and (2) the associated mafic rocks that record only Alpine metamorphism. A summary of rock types, sample location, mineralogy and $P-T$ peak conditions is provided in Table 1.

In the Malone Valley, located in the southern part of the EMC, strongly foliated blueschists are associated with garnet-bearing micaschists parallel to quartz layers around which lawsonite pseudomorphs are preserved (Online Resource 1). Two metasediments and an eclogite were sampled near Alpe Mecio, $2.5 \mathrm{~km}$ South-West of Monte Soglio. Sample AV16-44 is a fine-grained glaucophane-epidote-garnet bearing schist (referred to as blueschist in the following) containing $\mathrm{mm}$-sized garnet porphyroblasts surrounded by the foliation, preserving a fractured core and an epidote inclusion-rich rim. Sample AV16-45 is a quartz-rich, garnet-bearing micaschist with phengite, paragonite, chlorite and allanite defining a foliation that wraps around mm-sized garnet porphyroblasts. Sample AV16-47 is a weakly foliated mafic boudin in metasediments, mainly composed of glaucophane, epidote and euhedral garnet grains with a size of $100-500 \mu \mathrm{m}$. It contains lenses rich in omphacite and surrounded by epidote.

The Ivozio Complex is a metagabbro body with a diameter of $\sim 500 \mathrm{~m}$ (Pognante et al. 1980; Zucali et al. 2004). This mafic complex is associated with scarce ultramafic lenses and is surrounded by micaschists (Online Resource 1). Sample AV16-21 is an eclogite with two domains: (1) a glaucophane-bearing eclogite, dominated by garnet and omphacite, and (2) a quartz-rich domain containing millimetre-sized, deformed phengite and garnet with a core rich in inclusions of quartz, phengite and rutile.

Sample VC10-04 was collected in the Chiusella Valley, west of Cima di Bonze near Alpe Solanger. Here, metagabbros are associated with thin bands of Mn-rich metaquartzite (Venturini et al. 1994; Rubatto 1998; Zucali 2002) (Online Resource 1). Sample VC10-04 is a Mn-rich metaquartzite, characterized by an intense foliation marked by elongated glaucophane blasts, quartz and pink garnet crystals with atoll texture.

Typical eclogitic micaschists found in the Lys Valley, in the central part of the EMC, are compositionally banded, with an alternation of strongly foliated phyllosilicate-rich 
Table 1 List of the analysed samples. Coordinates refer to WGS84. Mineral abbreviations are from Whitney and Evans (2010)

\begin{tabular}{|c|c|c|c|c|}
\hline Sample & Location & Lithology & Mineralogy (vol\% based on visual estimation) & Peak $P-T$ \\
\hline \multicolumn{5}{|c|}{ Malone Valley } \\
\hline AV16-44 & $\begin{array}{l}\mathrm{N} 45^{\circ} 21^{\prime} 29.64^{\prime \prime} \\
\text { E } 09^{\circ} 31^{\prime} 03.00^{\prime \prime}\end{array}$ & Blueschist & $\begin{array}{l}\mathrm{Gln}(50 \%)+\mathrm{Grt}(20 \%)+\mathrm{Spn}(10 \%) \pm \mathrm{Ep} \pm \mathrm{Ph} \pm \mathrm{Aln} \pm \mathrm{Ap} \pm \mathrm{Cpx} \pm \mathrm{Chl} \\
\quad \text { (retr.) } \pm \text { Amp (retr.) } \pm \mathrm{Zrn}\end{array}$ & $\begin{array}{l}\sim 1.7 \mathrm{GPa}, \\
500{ }^{\circ} \mathrm{C}^{\mathrm{a}}\end{array}$ \\
\hline AV16-45 & $\begin{array}{l}\mathrm{N} 45^{\circ} 21^{\prime} 29.64^{\prime \prime} \\
\text { E } 09^{\circ} 31^{\prime} 03.00^{\prime \prime}\end{array}$ & Micaschist & $\mathrm{Qz}(35 \%)+\mathrm{Ph}(35 \%)+\operatorname{Grt}(15 \%)+\mathrm{Pg}(5 \%) \pm \mathrm{Chl} \pm \mathrm{Ab} \pm \mathrm{Spn} \pm \mathrm{Aln} \pm \mathrm{Zrn}$ & $\begin{array}{l}\sim 1.7 \mathrm{GPa}, \\
500{ }^{\circ} \mathrm{C}^{\mathrm{a}}\end{array}$ \\
\hline AV16-47 & $\begin{array}{l}\mathrm{N} 45^{\circ} 21^{\prime} 29.64^{\prime \prime} \\
\text { E } 09^{\circ} 31^{\prime} 03.00^{\prime \prime}\end{array}$ & Eclogite & $\begin{array}{l}\text { Matrix: Gln }(50 \%)+\operatorname{Grt}(20 \%)+\mathrm{Ep}(15 \%) \pm \mathrm{Ph} \pm \mathrm{Zo} \pm \mathrm{Ap} \pm \mathrm{Chl} \\
\quad(\text { retr. } \pm \text { Amp (retr.) } \pm \mathrm{Ab}(\text { (retr. }) \pm \mathrm{Spn} \pm \mathrm{Zrn} \\
\text { Boudin core: Omp }(90 \%) \pm \mathrm{Spn} \pm \mathrm{Amp}(\text { retr. }) \pm \mathrm{Ab} \text { (retr.); rim: Ep } \\
\quad(55 \%)+\mathrm{Spn}(35 \%) \pm \mathrm{Grt} \pm \mathrm{Zrn}\end{array}$ & $\begin{array}{l}\sim 1.7 \mathrm{GPa}, \\
500{ }^{\circ} \mathrm{C}^{\mathrm{a}}\end{array}$ \\
\hline \multicolumn{5}{|c|}{ Ivozio Complex } \\
\hline AV16-21 & $\begin{array}{l}\mathrm{N} 45^{\circ} 32^{\prime} 09^{\prime \prime} \\
\mathrm{E} 07^{\circ} 50^{\prime} 46^{\prime \prime}\end{array}$ & Eclogite & $\begin{array}{l}\text { Mafic layer: Grt }(50 \%)+\operatorname{Omp}(25 \%)+\mathrm{Gln}(15 \%) \pm \mathrm{Ph} \pm \mathrm{Rt} \pm \mathrm{Py} \\
\text { Qz-rich layer: Qz }(30 \%)+\operatorname{Grt}(30 \%)+\mathrm{Ph}(30 \%) \pm \mathrm{Ep} \pm \mathrm{Rt}\end{array}$ & $\begin{array}{l}1.8-2.3 \mathrm{GPa}, \\
550-600{ }^{\circ} \mathrm{C}^{\mathrm{b}}\end{array}$ \\
\hline \multicolumn{5}{|c|}{ Cima di Bonze } \\
\hline VC10-04 & $\begin{array}{l}\mathrm{N} 45^{\circ} 33^{\prime} 03.70^{\prime \prime} \\
\text { E } 07^{\circ} 43^{\prime} 43.20^{\prime \prime}\end{array}$ & Impure metaquartzite & $\mathrm{Qz}(60 \%)+\mathrm{Grt}(20 \%)+\mathrm{Gln}(15 \%) \pm \mathrm{Aln} \pm \mathrm{Zrn}$ & $\begin{array}{l}\sim 1.8 \mathrm{GPa} \text {, } \\
550{ }^{\circ} \mathrm{C}^{\mathrm{c}}\end{array}$ \\
\hline \multicolumn{5}{|l|}{ Lys Valley } \\
\hline FG1249 & $\begin{array}{l}\text { N } 45^{\circ} 37^{\prime} 57.53^{\prime \prime} \\
\text { E } 07^{\circ} 48^{\prime} 07.79^{\prime \prime}\end{array}$ & Micaschist & $\begin{array}{l}\mathrm{Qz}(40 \%)+\mathrm{Ph}(20 \%)+\mathrm{Pg}(10 \%)+\mathrm{Grt}(15 \%) \pm \mathrm{Ep} \pm \mathrm{Chl} \pm \mathrm{Ab} \pm \mathrm{Rt} \pm \mathrm{Gln} \\
\quad \pm \mathrm{Zrn} \pm \mathrm{Gr}\end{array}$ & $\begin{array}{l}\sim 1.6 \mathrm{GPa} \\
620^{\circ} \mathrm{C}^{\mathrm{d}}\end{array}$ \\
\hline FG1315 & $\begin{array}{l}\mathrm{N} 45^{\circ} 36^{\prime} 42.26^{\prime \prime} \\
\text { E } 07^{\circ} 49^{\prime} 36.05^{\prime \prime}\end{array}$ & Micaschist & $\begin{array}{l}\mathrm{Qz}(40 \%)+\mathrm{Ph}(25 \%)+\mathrm{Pg}(15 \%)+\mathrm{Grt}(15 \%) \pm \mathrm{Ep} \pm \mathrm{Chl} \pm \mathrm{Ab} \pm \mathrm{Rt} \pm \mathrm{Gln} \pm \\
\mathrm{Zrn} \pm \text { opaques }\end{array}$ & $\begin{array}{l}\sim 1.9 \mathrm{GPa} \\
6500^{\circ} \mathrm{C}^{\mathrm{d}}\end{array}$ \\
\hline \multicolumn{5}{|c|}{ Monte Mucrone } \\
\hline AV17-07 & $\begin{array}{l}\text { N } 45^{\circ} 37^{\prime} 52.98^{\prime \prime} \\
\text { E } 07^{\circ} 56^{\prime} 23.58^{\prime \prime}\end{array}$ & Micaschist & $\begin{array}{l}\mathrm{Ph}(35 \%)+\mathrm{Grt}(35 \%)+\mathrm{Pg}(15 \%)+\mathrm{Qz}(5 \%) \pm \mathrm{Rt} \pm \mathrm{Aln} \pm \mathrm{Zrn} \pm \mathrm{Chl} \pm \mathrm{Cpx} \\
\quad(\text { relics }) \pm \text { opaques }\end{array}$ & $\begin{array}{l}1.3-.15 \mathrm{GPa}, \\
500-600{ }^{\circ} \mathrm{C}^{\mathrm{e}}\end{array}$ \\
\hline AV17-16 & $\begin{array}{l}\text { N } 45^{\circ} 37^{\prime} 51.18^{\prime \prime} \\
\text { E } 07^{\circ} 56^{\prime} 34.24^{\prime \prime}\end{array}$ & Eclogite & $\begin{array}{l}\text { Matrix: } \operatorname{Gln}(30 \%)+\operatorname{Grt}(25 \%)+\operatorname{Omp}(20 \%)+\mathrm{Ph}(10 \%)+\mathrm{Pg} \\
\quad(5 \%) \pm \mathrm{Rt} \pm \mathrm{Ap} \pm \mathrm{Zrn} \\
\text { Veins: } \mathrm{Ph}(40 \%)+\mathrm{Grt}(30 \%)+\mathrm{Gln}(20 \%) \pm \mathrm{Rt} \pm \mathrm{Ep}\end{array}$ & $\begin{array}{l}1.3-.15 \mathrm{GPa}, \\
500-600{ }^{\circ} \mathrm{C}^{\mathrm{e}}\end{array}$ \\
\hline
\end{tabular}

retr. retrograde

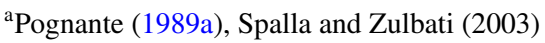

${ }^{\mathrm{b}}$ Zucali et al. (2004), Zucali and Spalla (2011)

${ }^{\mathrm{c}}$ Regis et al. (2014)

${ }^{\mathrm{d}}$ Giuntoli et al. (2018b)

${ }^{\mathrm{e}}$ Zucali et al. (2002) and references therein

layers, quartz-rich gneissic layers and mafic layers (Online Resource 1). A detailed textural and mineralogical description of samples FG1249 and FG1315 is given in Giuntoli et al. (2018a, b). Sample FG1249 is a garnet-bearing micaschist with phengite, paragonite, allanite, and rutile defining a foliation that wraps around garnet of several millimetres size. Sample FG1315 is a garnet-bearing micaschist with a pervasive foliation marked by phengite, paragonite and allanite. Garnet is present as both mm-sized grains, preserving a porphyroclastic core overgrown by multiple rims, and atoll grains a few hundred microns in size.

The Monte Mucrone area between Albergo Savoia and Bocchetta del Lago is dominated by micaschists and paragneisses including centimetric to metric mafic lenses and boudins and locally preserving relics of migmatitic textures (Online Resource 1). Sample AV17-07 is a garnetmicaschist containing quartz, large (hundreds of microns in size) phengite, and lozenge-shape aggregates of fine-grained paragonite. In this sample, two main garnet textures are observed: (1) millimetre porphyroclastic cores surrounded by euhedral smaller garnet crystals and (2) submillimetre euhedral grains locally forming atoll garnet textures. Sample AV17-16 is a decametric eclogite layer composed of glaucophane, garnet, omphacite, paragonite, phengite and minor quartz and rutile; it contains pods and veins of coarsegrained phengite, garnet and glaucophane. Garnet is characterized by cloudy, glaucophane and quartz inclusion-rich cores and inclusion-free rims.

\section{Analytical methods}

\section{SEM imaging and EPMA major element analysis}

Back scattered electron images were obtained with a ZEISS EVO 50 scanning electron microscope at the Institute of 
Geological Sciences (University of Bern) using a voltage of $20 \mathrm{kV}$, a specimen current of $\sim 1 \mathrm{nA}$ and a working distance of $10 \mathrm{~mm}$.

Electron probe micro-analysis (EPMA) was performed using a JEOL JXA-8200 superprobe at the Institute of Geological Sciences (University of Bern). For X-ray maps acquisition, the procedure described in Lanari et al. (2014, 2019) was followed. For spot analyses, analytical conditions were $15 \mathrm{kV}$ accelerating voltage, $10-20 \mathrm{nA}$ specimen current, $40 \mathrm{~s}$ dwell time (including $20 \mathrm{~s}$ of peak measurement time and $10 \mathrm{~s}$ of background measurement before and after) and a beam diameter from 1 to $5 \mu \mathrm{m}$. Nine oxide compositions were measured, using synthetic and natural standards: wollastonite/orthoclase/almandine $\left(\mathrm{SiO}_{2}\right)$, anorthite/almandine $\left(\mathrm{Al}_{2} \mathrm{O}_{3}\right)$, anorthite $(\mathrm{CaO})$, almandine $(\mathrm{FeO})$, forsterite $(\mathrm{MgO})$, orthoclase/phlogopite $\left(\mathrm{K}_{2} \mathrm{O}\right)$, albite $\left(\mathrm{Na}_{2} \mathrm{O}\right)$, ilmenite $\left(\mathrm{TiO}_{2}\right)$ and tephroite $(\mathrm{MnO})$. For X-ray maps, analytical conditions were $15 \mathrm{kV}$ accelerating voltage, $100 \mathrm{nA}$ specimen current and dwell times of 80-160 ms. Nine elements ( $\mathrm{Si}$, Ti, $\mathrm{Al}, \mathrm{Fe}, \mathrm{Mn}, \mathrm{Mg}, \mathrm{Na}, \mathrm{Ca}$ and $\mathrm{K}$ ) were measured at the specific wavelength in two passes. Intensity maps were standardized using spot analyses as internal standard. X-ray maps were processed using XMAPToOLs software (Lanari et al. 2014, 2019). Mineral structural formulas were computed for each mineral group based on the following oxygen basis: garnet 12 , micas 11 , amphibole 23 , chlorite 28 , epidote 25 , pyroxene 6 and plagioclase 8 .

\section{LA-ICP-MS trace element analysis}

Trace element spot analyses of garnet were performed by LA-ICP-MS by a Geolas Pro $193 \mathrm{~nm}$ ArF excimer laser coupled to an Elan DRC-e quadrupole ICP-MS and by a RESOlution Laser System coupled to an Agilent 7900 quadrupole ICP-MS at the Institute of Geological Sciences (University of Bern). A $\mathrm{He}-\mathrm{H}_{2}$ gas mixture was used as the aerosol transport gas. Garnet trace element analyses were performed with laser beam diameters of 38,50 and $60 \mu \mathrm{m}$, frequencies of 10 and $5 \mathrm{~Hz}$ and energy densities on the sample of 8.0 and $4.5 \mathrm{~J} \mathrm{~cm}^{-2}$. Sample analyses were calibrated using NIST SRM 612 (Jochum et al. 2011) and GSD-1G (Jochum et al. 2005) using $\mathrm{Si}$ as internal standard. Accuracy was monitored using the reference material BCR-2 and GSD-1G (Jochum et al. 2005) or NIST SRM 612 (Jochum et al. 2011) (detail given in Online Resource 2). Data reduction was performed using the SILLS software package (Guillong et al. 2008) and Iolite software (Hellstrom et al. 2008; Paton et al. 2011).

\section{Oxygen isotope analysis}

${ }^{18} \mathrm{O} /{ }^{16} \mathrm{O}$ ratios were measured for all the samples except VC10-04 using the SwissSIMS Cameca IMS 1280HR instrument at University of Lausanne (Switzerland). Analytical
Fig. 2 Garnet major element composition for the eclogite samples. a Grossular vs. spessartine content in garnet. b Grossular vs. pyrope content in garnet. In $\mathbf{a}$ and $\mathbf{b}$ arrows indicate the zoning from core to rim. $\mathrm{Qz}=$ quartz. $\mathbf{c}-\mathbf{n}$ Compositional maps for each sample showing $X_{\mathrm{Grs}}, X_{\mathrm{Sps}}$ and $X_{\mathrm{Prp}}$. Grey dots in the $X_{\mathrm{Grs}}$ map indicate the location of the oxygen isotope analyses

conditions followed Seitz et al. (2017). A $10 \mathrm{kV}^{133} \mathrm{Cs}^{+}$primary Gaussian ion beam was used with a 1.6-2.0 nA current. This resulted in a typical spot size of $15-20 \mu \mathrm{m}$. The electron flood gun was used to compensate surface charge. A pre-sputtering time of $30 \mathrm{~s}$ was applied to remove the gold coating, followed by automated secondary beam centring and 20 cycles of $5 \mathrm{~s}$ data acquisition. Oxygen isotope ratios $\left({ }^{18} \mathrm{O} /{ }^{16} \mathrm{O}\right)$ are expressed in delta notation $\left(\delta^{18} \mathrm{O}\right.$ in \%o) relative to the Vienna Standard Mean Ocean Water (VSMOW). For garnet, UWG2 garnet $\left(\delta^{18} \mathrm{O}=5.8 \%\right.$, Valley et al. 1995) was measured as primary standard. Garnet GRS-JH2 (Vho et al. 2020b) was used as secondary reference material. An off-line matrix bias correction for the grossular (in all cases) and spessartine (whenever necessary) components of garnet was applied following the procedure given in Vho et al. (2020b). The garnet composition for each SIMS spot was based on average composition calculated from the compositional maps using XMAPToOLs or using a close set of EPMA spot analyses.

${ }^{18} \mathrm{O} /{ }^{16} \mathrm{O}$ ratios in the sample $\mathrm{VC} 10-04$ were measured using the SHRIMP-SI ion microprobe at the Australian National University (ANU). The analysis protocol is detailed in Martin et al. (2014b) and UWG2 garnet was measured as primary standard. An off-line matrix bias correction for the grossular and spessartine component of garnet was applied following the procedure given in Martin et al. (2014b) based on EDS compositional analyses performed with the JEOL JSM 6610-A scanning electron microscope at ANU.

\section{Results}

\section{Garnet textures and composition}

\section{Eclogites}

Garnet in eclogites (AV16-47 from Malone Valley, AV16-21 from Ivozio Complex and AV17-16 from Monte Mucrone) is typically characterized by a growth-related major element compositional zoning, with a Mn-rich core and $\mathrm{Ca}$ decreasing from core to rim (Fig. 2). For this garnet type, the terms 'core', 'mantle' and 'rim' are used to indicate different crystal domains distinguishable on the base of textures combined with major or trace element composition. Representative major element analyses of all the garnet domains are reported in Online Resource 5. Trace element analyses 


\section{ECLOGITES}
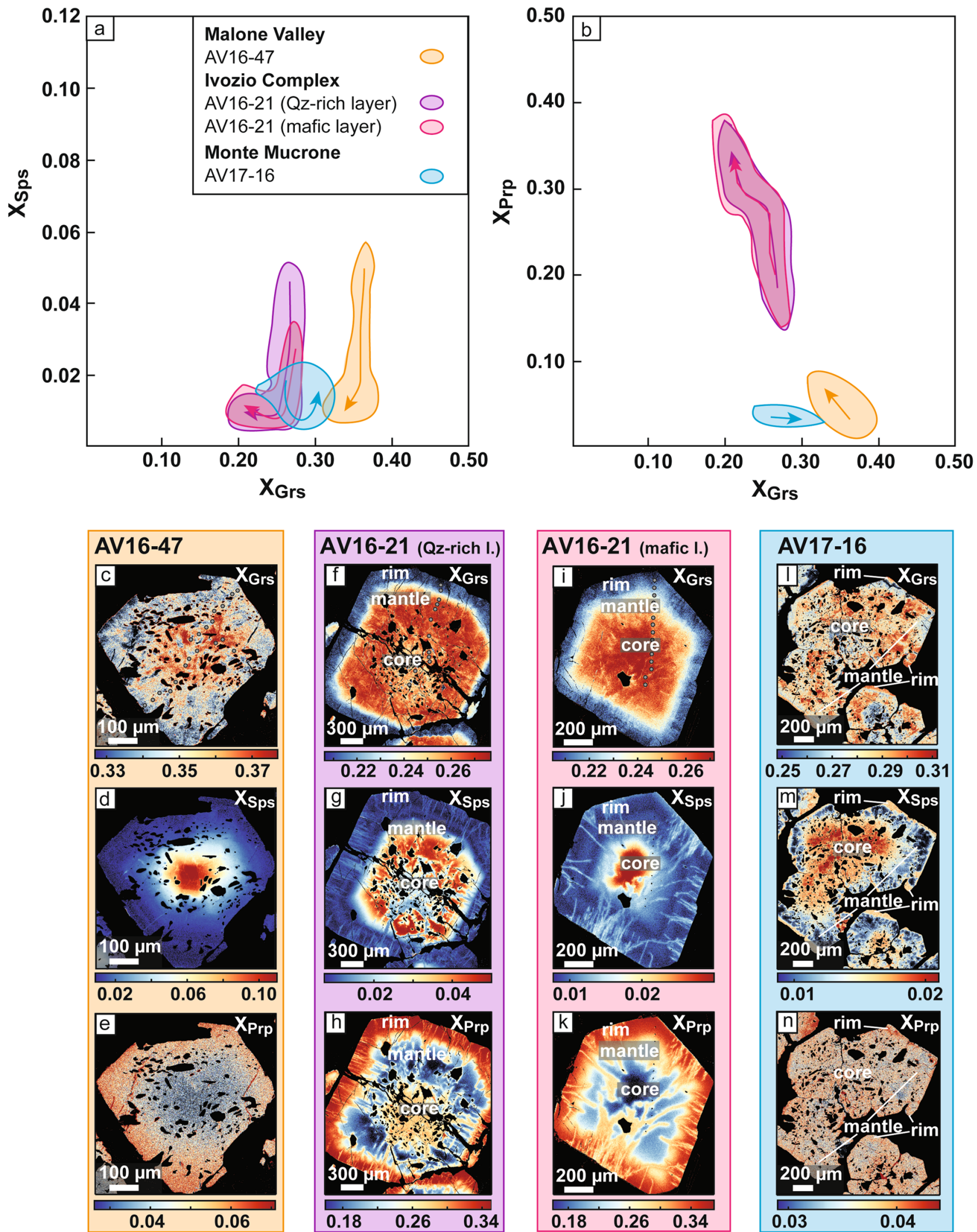
are reported in Online Resource 6, whereas chondrite normalised REE plots are presented in Online Resource 3.

Garnet in eclogite AV16-47 from Malone Valley shows a major element zonation with $X_{\mathrm{Sps}}$ decreasing from core to rim (0.12-0.01), typical of prograde metamorphism, and a patchy zoning in $\mathrm{Ca}$, with $X_{\mathrm{Grs}}$ decreasing toward the rim (0.40-0.30) (Fig. 2). By contrast $X_{\mathrm{Prp}}$, as well as $X_{\mathrm{Alm}}$, increases from core to rim (Fig. 2; Online Resource 3). Garnet core REE patterns are enriched in HREE, characterized by a steep increase with increasing atomic mass $\left(\mathrm{Lu}_{N} / \mathrm{Dy}_{\mathrm{N}}\right.$ up to 125) (Fig. 3; Online Resource 3). The HREE patterns become flat to moderately concave-down in the mantle and in the rim $\left(\mathrm{Lu}_{\mathrm{N}} / \mathrm{Dy}_{\mathrm{N}} \sim 1\right)$. The LREE are mostly below detection limit and the measured concentrations might be affected by contamination from epidote inclusions, therefore are not reported. The concentration of $\mathrm{Y}$ decreases from $\sim 10$ to $\sim 2 \mu \mathrm{g} / \mathrm{g}$ from core to rim (Fig. $3 \mathrm{~b}$ ).

In eclogite AV16-21 from Ivozio Complex, two different types of garnet are recognised: larger grains $(2-3 \mathrm{~mm})$ located in quartz- and phengite-rich domains, and smaller garnet grains $(<1.5 \mathrm{~mm})$ associated with glaucophane, omphacite and minor white mica. Both garnet types show a bell-shaped major element zonation pattern with decreasing
$X_{\mathrm{Grs}}$ and $X_{\mathrm{Sps}}$ from core to rim $(0.30-0.20$ and 0.03 or $0.05-0.01$, respectively; Fig. 2). The original core-rim zoning is crosscut by irregular and radial veins up to $30 \mu \mathrm{m}$ in width (referred to as 'veinlets' in the following) with intermediate $\mathrm{Mg}$ and $\mathrm{Mn}$ contents $\left(X_{\operatorname{Prp}} \sim 0.25\right.$ and $\left.X_{\mathrm{Sps}} \sim 0.02\right)$. The core is enriched in HREE, with a moderately steep HREE pattern $\left(\mathrm{Lu}_{N} / \mathrm{Dy}_{\mathrm{N}}=1.4-10.7\right)$. In the small garnet from the mafic layer, mantle and rim show similar REE patterns, $\sim 10$ times depleted in HREE with respect to the garnet core and with a low $\mathrm{Lu}_{N} / \mathrm{Dy}_{\mathrm{N}}=0.3-0.9$ (Fig. 3c). In the larger garnet from the quartz-rich layer, the rim is significantly enriched in MREE with respect to the garnet mantle. Europium anomaly $\left[\mathrm{Eu}_{\mathrm{N}} /\left(\mathrm{Sm}_{\mathrm{N}} \times \mathrm{Gd}_{\mathrm{N}}\right)^{0.5}\right]$ is absent in both garnet types (Fig. 3d). Yttrium is $\sim 3-5$ times enriched in the core and decreases toward the mantle; a sharp increase in the rim is observed in the garnet from the quartz-rich layer (Fig. 3e). The garnet composition in the veinlet network could not be analysed via single-spot LA-ICP-MS analysis (the used spot size was $60 \mu \mathrm{m}$ ). These features were analysed by high spatial resolution trace elements mapping in the garnet from the quartz-rich layer by Rubatto et al. (2020).

Garnet in eclogite AV17-16 from Monte Mucrone is characterized by a general decrease in spessartine content
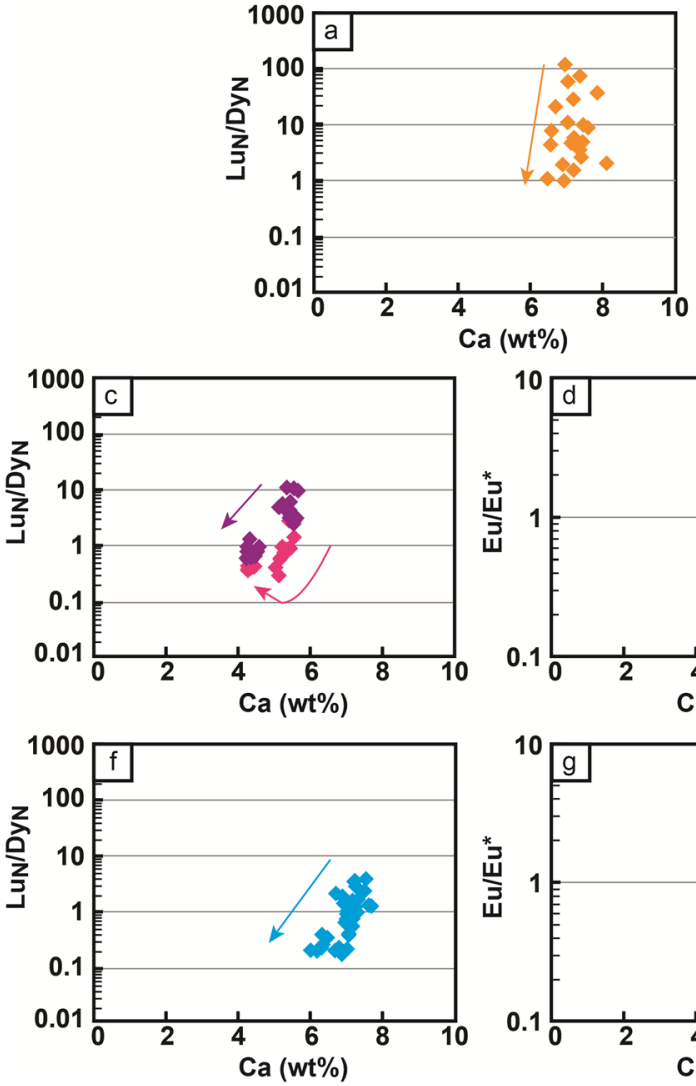
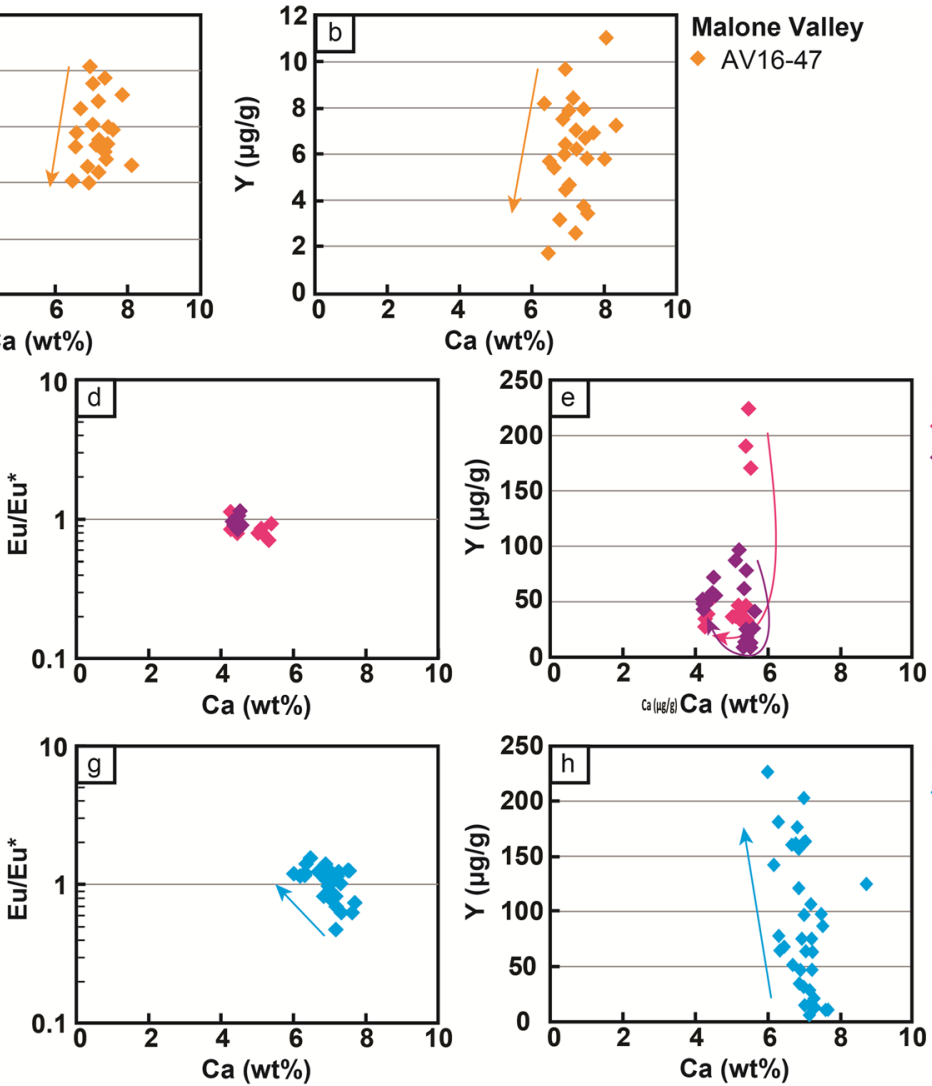

Ivozio Complex

- AV16-21 mafic layer - AV16-21 Qz-rich layer

Fig. 3 Garnet trace element composition for the eclogites divided by locality and sample. Arrows indicate the zoning from core to rim. $Q z=$ quartz 
from core to mantle $(0.02$ to $<0.01$, Fig. 2). Grossular zoning is patchy but decreases from core to mantle with a less regular pattern than that of spessartine. A discontinuous rim with $X_{\mathrm{Sps}}=0.02, X_{\mathrm{Alm}}=0.65$ and $X_{\mathrm{Grs}}=0.30$ is clearly distinguishable from the garnet mantle composition (Fig. 2; Online Resource 3). No systematic correlation between the type of neighbouring phases and the rim occurrence was observed. The $X_{\mathrm{Sps}}$ map shows that a network of radial veinlets with a width of $20-50 \mu \mathrm{m}$ and intermediate $X_{\mathrm{Sps}}$ propagates from the rim and affects the mantle. Garnet core shows a flat to moderately increasing HREE pattern $\left(\mathrm{Lu}_{\mathrm{N}} /\right.$ $\mathrm{Dy}_{\mathrm{N}}$ up to 3.8) and relatively low $\mathrm{Y}$ content $(5-30 \mu \mathrm{g} / \mathrm{g})$ (Fig. 3f-h). The garnet mantle REE pattern is characterized by a concave-down shape $\left(\mathrm{Lu}_{\mathrm{N}} / \mathrm{Dy}_{\mathrm{N}}=0.2-1.0\right)$, and it is enriched in MREE and Y with respect to the core (up to $200 \mu \mathrm{g} / \mathrm{g}$ ). The garnet rim is characterized by a distinctly higher MREE and $Y$ contents and comparable concave shape $\left(\mathrm{Dy}_{\mathrm{N}} / \mathrm{Lu}_{\mathrm{N}}=0.2-0.4\right)$. A Eu negative anomaly is absent.

In summary, garnet grains in the eclogite samples show a continuous growth zoning marked by a bell-shaped profile of grossular and spessartine in AV16-21, or patchy zoning in grossular in AV16-47 and AV17-16. Garnet grains in the eclogites do not show evidence of growth interruption and resorption stages, except for the presence of late veinlets in garnet from sample AV16-21 and AV17-16, and a discontinuous rim in the latter sample. The significance of these secondary features is discussed below.

\section{Metasediments}

Garnet in metasediments (AV16-44 and AV16-45 from Malone Valley, VC10-04 from Chiusella Valley, FG1249 and FG1315 from Lys Valley, and AV17-07 from Monte Mucrone) displays more complex textures, with a distinct core, typically showing lobate edges, veins of few micrometers in size of garnet with different composition ('veinlets') and fractures, and one or more rims with sharp compositional boundaries with the core (Fig. 4; Online Resource 3). This garnet type is described in terms of core and rim. In order to render the complexity of the rim, 'inner and outer rim' are used when rims show no or continuous zoning, while a distinction between different rim generations (i.e., rim1, rim2) is made when they display a sharp variation in major or trace element compositions.

In blueschist AV16-44 from Malone Valley, garnet shows distinct core and rim compositions (Fig. 4). The core has low $X_{\text {Grs }}(0.05-0.07)$ with respect to the rim $(0.30-0.35)$. Pyrope content is higher in the core $(0.10)$ than in the rim (0.02-0.06). Almandine and spessartine core compositions do not follow the $\mathrm{Ca}$ increase toward the outer core, but show patchy zoning characterized by domains of higher $X_{\mathrm{Sps}}(0.15-0.17)$ and lower $X_{\mathrm{Alm}}(0.67-0.69)$ cut by irregular veinlets with lower $X_{\mathrm{Sps}}(0.07)$ and higher $X_{\mathrm{Alm}}(0.75-0.78)$.
The core shows fractures of $10-30 \mu \mathrm{m}$ where garnet of rim composition is found. Garnet core REE patterns are enriched in HREE, with a flat to moderately concave-down shape $\left(\mathrm{Lu}_{\mathrm{N}} / \mathrm{Dy}_{\mathrm{N}}=0.2-1.0\right)$ and a pronounced negative Eu anomaly of 0.2-0.4 (Fig. 5a,b; Online Resource 3). Garnet rims are disseminated with $\mu \mathrm{m}$-sized epidote and titanite inclusions, resulting in contamination of the rim trace element analyses, particularly for LREE and Eu. Due to this issue, the garnet Eu anomaly could not be calculated. Heavy REE garnet rim pattern is characterized by a concave-down shape $\left(\mathrm{Lu}_{\mathrm{N}} /\right.$ $\mathrm{Dy}_{\mathrm{N}}=0.4-17$ ) (Fig. 5a). Yttrium is up 10 times higher in the core than in the rim and shows a significant variation within the core that does not correlate with the $\mathrm{Fe}$ and $\mathrm{Mn}$ zoning (Fig. 5c).

In micaschist AV16-45 from Malone Valley, garnet porphyroblasts have distinct core and rim compositions separated by a sharp compositional boundary (Fig. 4; Online Resource 3). Garnet rim distribution is discontinuous around the core and has a maximum thickness of $\sim 150 \mu \mathrm{m}$. Locally $30-60 \mu \mathrm{m}$-thick fractures filled with garnet of rim composition crosscut the garnet core (Fig. 4). The core is depleted in Ca with respect to the rim, with $X_{\mathrm{Grs}}$ of $0.03-0.04$, and is affected by a network of $\sim \mu \mathrm{m}$-thick veinlets of garnet with higher $X_{\text {Grs }}$ (up to 0.20) (Fig. 4). The compositional maps of $\mathrm{Fe}, \mathrm{Mg}$ and $\mathrm{Mn}$ show the presence of a faint zoning in the core, characterized by patchy domains (referred to as inner core) with higher $X_{\text {Alm }}$ (up to 0.80) and $X_{\operatorname{Prp}}$ (up to 0.16 ) (Fig. 4; Online Resource 3). The garnet core has a high HREE content with a pattern that varies from a moderate increase from Dy to $\mathrm{Lu}\left(\mathrm{Lu}_{\mathrm{N}} / \mathrm{Dy}_{\mathrm{N}} \sim 3\right)$ to a significant decrease $\left(\mathrm{Lu}_{\mathrm{N}} / \mathrm{Dy}_{\mathrm{N}} \sim 0.3\right)$ (Fig. 5a). Eu negative anomaly varies between $0.17-0.41$ in the core (Fig. $5 b$ ). No clear correlation exists between the major element zoning and the HREE variation; however, the outer core where the veining is most abundant generally has higher HREE, possibly due to contamination from the veinlet garnet. From inner to outer rim, the HREE pattern changes systematically, from slightly decreasing $\left(\mathrm{Lu}_{N} / \mathrm{Dy}_{\mathrm{N}}=1.5-2.5\right)$ to relatively flat $\left(\mathrm{Lu}_{\mathrm{N}} / \mathrm{Dy}_{\mathrm{N}} \sim 1\right)$ to depleted in HREE $\left(\mathrm{Lu}_{\mathrm{N}} / \mathrm{Dy}_{\mathrm{N}}\right.$ down to $\left.\sim 0.1\right)$. Europium anomaly is absent in the rim and $\mathrm{Y}$ shows a minor decrease from inner core to outer rim (Fig. 5c).

Garnet in metaquartzite VC10-04 from Chiusella Valley is characterised by a mushroom-texture atoll (Robyr et al. 2013) with a corroded core and a euhedral rim (Fig. 4). End-member compositional maps reveal a complex zoning (Fig. 4; Online Resource 3). The garnet core is characterized by patches with relatively higher $\mathrm{Mn}$ and lower $\mathrm{Fe}\left(X_{\mathrm{Sps}}=0.15-0.35, X_{\mathrm{Alm}}=0.60-0.40\right)$, with minor variations in $X_{\mathrm{Grs}}(0.12-0.19)$ and $X_{\operatorname{Prp}}(0.06-0.08)$. The core has a lobate shape and the core-rim boundary is marked by a thin annulus showing an increase in both $\mathrm{Mn}$ and $\mathrm{Ca}$ and a decrease in Fe. Rim1 is characterized by distinct high Ca decreasing toward $\operatorname{rim} 2\left(X_{\mathrm{Grs}}=0.22-0.31\right)$, low $\mathrm{Mn}$ 


\section{METASEDIMENTS}
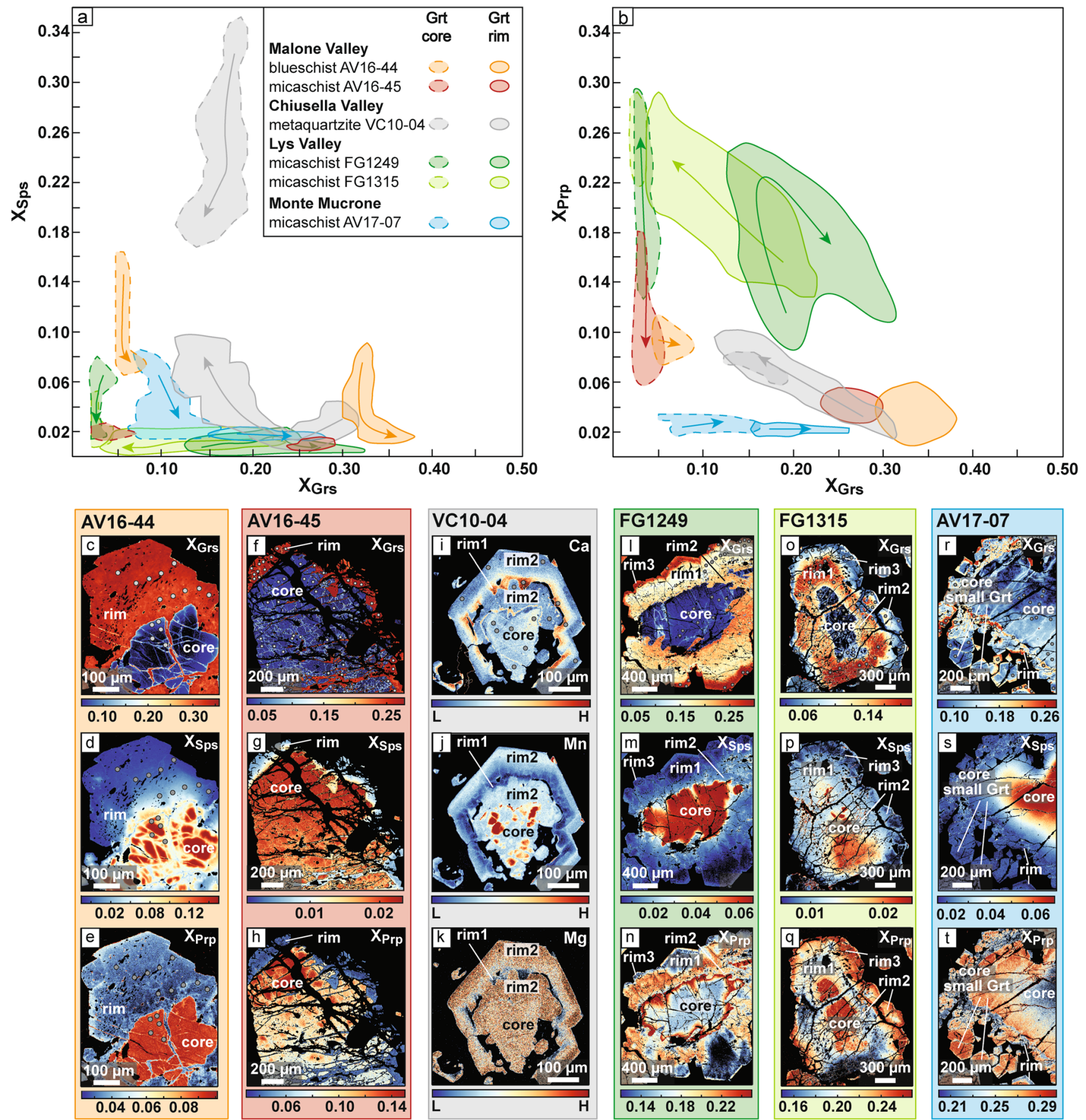

Fig. 4 Garnet major element composition for the metasediments AV16-44 and AV16-45 (Malone Valley), VC10-04 (Chiusella Valley), FG1249 and FG1315 (Lys Valley), and AV17-07 (Monte Mucrone). a Grossular vs. spessartine content in garnet. b Grossular

$\left(X_{\text {Sps }}<0.05\right)$ and $\operatorname{Mg}\left(X_{\operatorname{Prp}}=0.02-0.05\right.$, increasing toward rim2). Euhedral rim2 has a similar major element composition to the rim in the inner part of the atoll. The low $\mathrm{Ca}$ content in rim 2 can be explained by the scarce availability of $\mathrm{Ca}$ in the bulk composition of the metaquartzite. Garnet core vs. pyrope content in garnet. Arrows in $\mathbf{a}$ and $\mathbf{b}$ indicate the zoning from internal to external rim when present. c-t Compositional maps for each sample showing $X_{\mathrm{Grs}}, X_{\mathrm{Sps}}$ and $X_{\mathrm{Prp}}$. Grey dots in the $X_{\mathrm{Grs}}$ map indicate the location of the oxygen isotope analyses

shows a distinct REE pattern with high and flat HREE contents $\left(\mathrm{Lu}_{\mathrm{N}} / \mathrm{Dy}_{\mathrm{N}}=0.5-1.0\right)$ and a negative Eu anomaly $(\mathrm{Eu} /$ $\mathrm{Eu}^{*} \sim 0.5$ ) (Fig. 5d,e). The rim has markedly lower HREE with respect to the core. The core is strongly enriched in 

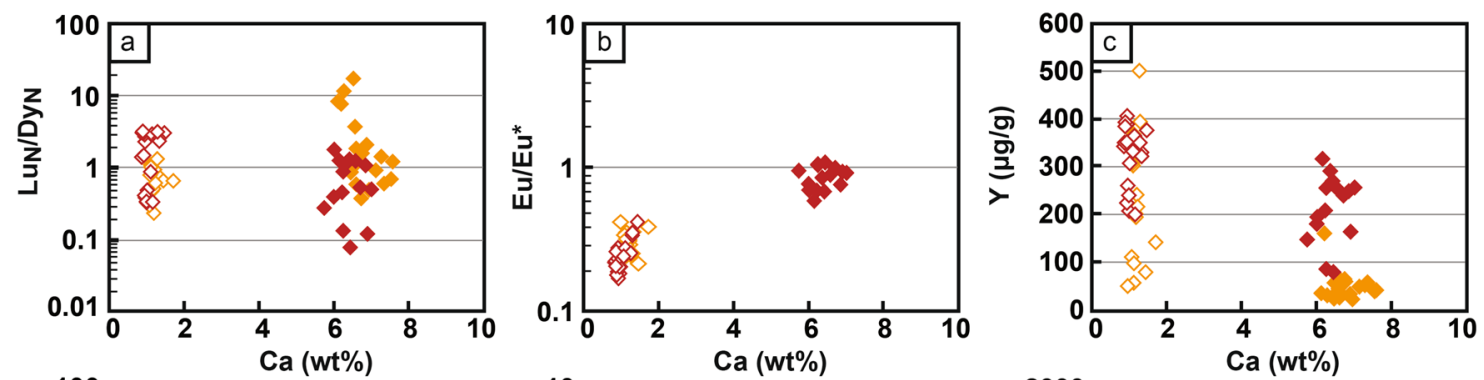

Malone Valley

AV16-44

$\diamond$ core

$\rightarrow$ rim

AV16-45

$\diamond$ core

$\diamond$ rim
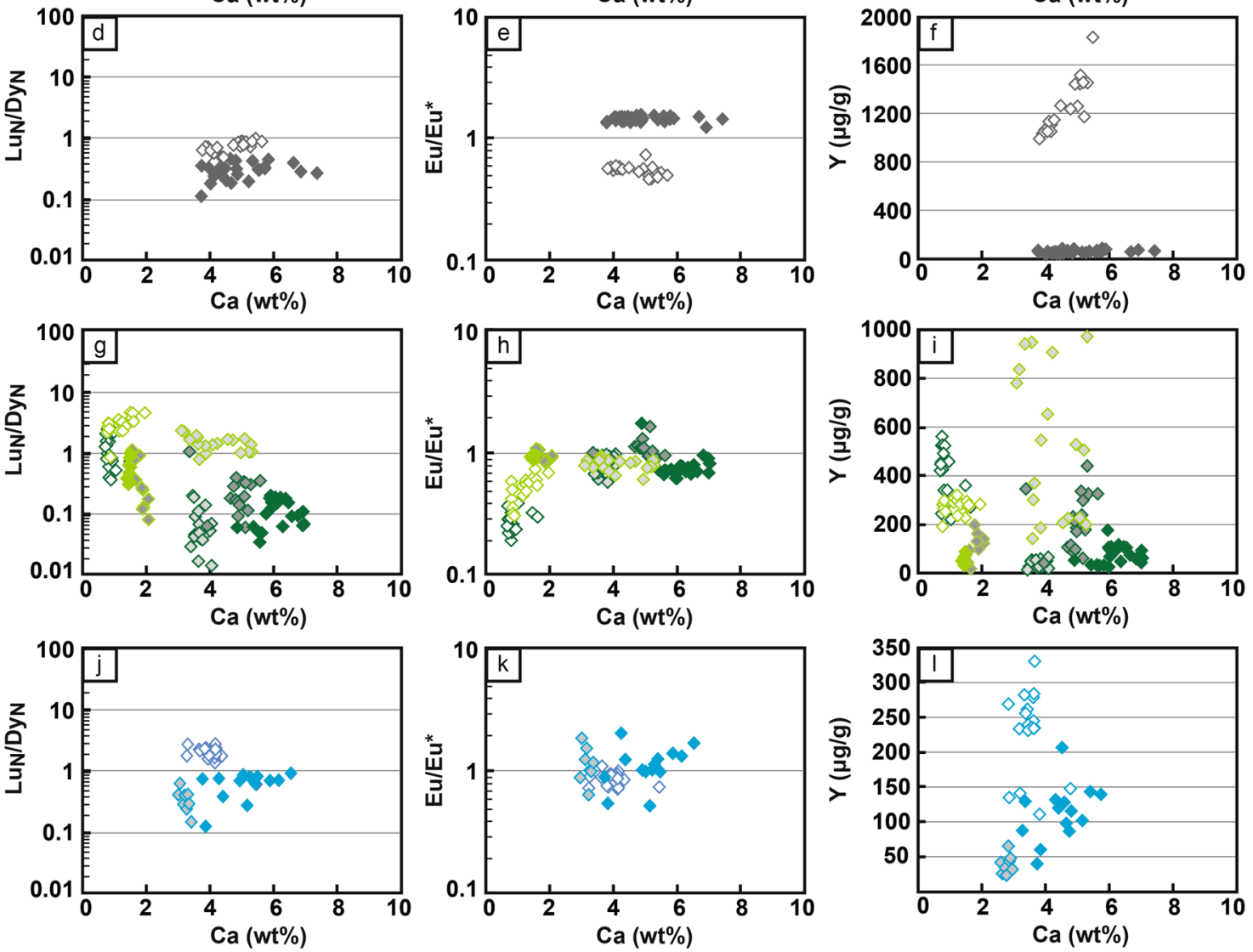

Chiusella Valley VC10-04

$\diamond$ core

- rim

Lys Valley

FG1249 FG1315

$\diamond$ core $\diamond$ core

$\diamond \operatorname{rim} 1 \diamond \operatorname{rim} 1$

$\diamond \operatorname{rim} 2 \Delta \operatorname{rim} 2$

$\downarrow \operatorname{rim} 3 \Delta \operatorname{rim} 3$

Fig. 5 Garnet trace element composition for the metasediments divided by locality and sample

$\mathrm{Y}(990-1670 \mu \mathrm{g} / \mathrm{g})$, with respect to the $\mathrm{rim}(30-85 \mu \mathrm{g} / \mathrm{g})$ (Fig. 5f).

A detailed description of major element zoning of micaschists FG1249 and FG1315 from Lys Valley is given in Giuntoli et al. (2018b). Based on major element zoning, the authors recognized a partly resorbed relict garnet core, attributed to the pre-Alpine evolution, and multiple rims. Here we present trace element data in relation to the major element zoning. The distinction between garnet zones follows the one defined by Giuntoli et al. (2018b). In micaschist FG1249, a core and three rim generations were recognized in the end-member compositional maps (Fig. 4; Online Resource 3). According to Giuntoli et al. (2018b), the core formed at granulite facies conditions, rim 1 at amphibolite facies conditions, and rim 2 and $\operatorname{rim} 3$ at eclogite facies conditions. The core has lower $X_{\mathrm{Grs}}(<0.10)$ and higher $X_{\text {Sps }}(0.05-0.07)$ with respect to the rims $\left(X_{\text {Grs }}=0.15-0.30\right.$, $\left.X_{\text {Sps }}<0.02\right)$ and shows a network of veinlets with higher grossular contents. Resorption is suggested by the presence of lobate boundaries around the core. Garnet core is enriched in HREE, characterized by a flat to moderately concave-down patterns $\left(\mathrm{Lu}_{\mathrm{N}} / \mathrm{Dy}_{\mathrm{N}}=0.3-2.3\right)$ and a pronounced negative $\mathrm{Eu}$ anomaly $\left(\mathrm{Eu} / \mathrm{Eu}^{*}=0.2-0.4\right)$ (Fig. 5g,h). The three rims are distinct in major and trace elements. $X_{\mathrm{Grs}}$ increases from rim1 to rim3. Rim1 is depleted in HREE with respect to the core, with strongly concave-down patterns $\left(\mathrm{Lu}_{\mathrm{N}} / \mathrm{Dy} \mathrm{N}_{\mathrm{N}}<0.2\right)$. Rim2 shows a relative increase in HREE content, while rim3 shows depletion in HREE that partly overlaps with rim1 composition. All three rims are also characterised by a weak to absent Eu anomaly (Eu/ 
$\mathrm{Eu}^{*}=0.6-1.0$ ) (Fig. 5g,h). Mimicking the HREE, Y is enriched in the core $(220-560 \mu \mathrm{g} / \mathrm{g})$, while rim1 is around ten times depleted with respect to the core. An increase up to core values is observed in rim 2 and is followed by a gradual decrease toward rim3 down to $20-30 \mu \mathrm{g} / \mathrm{g}$ (Fig. 5i).

In garnet from micaschist FG1315, a relict garnet core and three rims are recognized in the end-member compositional maps (Fig. 4; Online Resource 3). The core has low $X_{\text {Grs }}(<0.05), X_{\text {Prp }}=0.24-0.30, X_{\text {Alm }}=0.65-0.70$ and patchy zoning in $X_{\mathrm{Sps}}$. It shows a network of 5-15 $\mu \mathrm{m}$-wide veinlets that have higher $X_{\text {Grs }}$, up to 0.12 . The lobate shape of the core provides evidence for resorption. The corerim boundary is sharp in $X_{\mathrm{Grs}}, X_{\mathrm{Alm}}$ and $X_{\mathrm{Prp}}$. Rim1 contains quartz and rutile inclusions. Rim1, rim2 and rim3 are distinguished based on major element variations with a notable decrease in $X_{\text {Grs }}(0.20-0.25,0.10$ and $0.05-0.10$, respectively) and increase in $X_{\operatorname{Prp}}(0.10-0.20,0.23,0.30$, respectively). Garnet core REE patterns show a general increase from M-HREE $\left(\mathrm{Lu}_{\mathrm{N}} / \mathrm{Dy}_{\mathrm{N}}=2.2-4.7\right)$ and a negative Eu anomaly $\left(\mathrm{Eu} / \mathrm{Eu}^{*}=0.3-0.7\right)$ (Fig. 5g,h). The high grossular rim1 shows the highest content in Y $(142-907 \mu \mathrm{g} / \mathrm{g}$, Fig. 5i) and HREE with a flat pattern and no Eu anomaly. With decreasing Ca content, a decrease in HREE and Y contents is observed for rim 2 and rim 3 (rim2 $=98-198 \mu \mathrm{g} / \mathrm{g}$ and rim3 $=18-94 \mu \mathrm{g} / \mathrm{g}$ ). These two rims are characterized by a flat to concave-down HREE pattern $\left(\mathrm{Lu}_{\mathrm{N}} / \mathrm{Dy}_{\mathrm{N}}=0.1-1.0\right)$ (Fig. $5 \mathrm{~g}-\mathrm{i}$ ).

Garnet in micaschist AV17-07 from Monte Mucrone is characterized by the presence of $\mathrm{mm}$-size cores surrounded by an aggregate of euhedral garnet grains that are $100-200 \mu \mathrm{m}$ in size. In the core, spessartine and almandine contents decrease with increasing pyrope component toward the outer core $\left(X_{\mathrm{Sps}} 0.08-0.01, X_{\mathrm{Alm}} 0.65-0.55\right.$ and $X_{\operatorname{Prp}} 0.15-0.30$ ), whereas grossular mildly increases (0.06-0.14) (Fig. 4; Online Resource 3). The Ca compositional map shows that the core is characterized by a system of nearly parallel veinlets $10-20 \mu \mathrm{m}$ in size with higher $X_{\mathrm{Grs}}$ (up to 0.20). The euhedral grains have a core with similar $\mathrm{Ca}, \mathrm{Mg}$ and $\mathrm{Fe}$ content to the outer part of the large core $\left(X_{\text {Grs }}=0.08-0.10, X_{\mathrm{Alm}}=0.60-0.65, X_{\mathrm{Prp}}=0.30\right)$. Around both the core and the euhedral garnet grains, a rim enriched in $\mathrm{Ca}$ and depleted in $\mathrm{Fe}$ and $\mathrm{Mg}$ is present $\left(X_{\mathrm{Grs}}=0.20-030\right.$, $\left.X_{\text {Alm }}=0.45-0.50, X_{\operatorname{Prp}}=0.20-0.25\right)$. The garnet core has a relatively flat HREE patter $\left(\mathrm{Lu}_{\mathrm{N}} / \mathrm{Dy}_{\mathrm{N}}=1.4-2.8\right)$, with a slightly negative Eu anomaly $\left(\mathrm{Eu} / \mathrm{Eu}^{*}=0.7-0.8\right)($ Fig. $5 \mathrm{j}, \mathrm{k})$. The inner part of the small grains surrounding the large core are ten times depleted in HREE with respect to the core, with abundances decreasing with atomic mass $\left(\mathrm{Lu}_{\mathrm{N}} /\right.$ $\left.\mathrm{Dy}_{\mathrm{N}}=0.2-0.6\right)$. The high $X_{\mathrm{Grs}}$ rims are enriched in HREE with respect to the inner parts of the small grains and show a flat pattern $\left(\mathrm{Lu}_{\mathrm{N}} / \mathrm{Dy}_{\mathrm{N}}=0.7-0.9\right)$ (Fig. $\left.5 \mathrm{j}\right)$. Few analyses display an anomalous enrichment in Dy-Gd that could be related to the presence of MREE-rich micro-inclusions.
Fig. 7 Oxygen isotope composition of metasediments $\left(\delta^{18} \mathrm{O}\right.$ in $\%$. vs. VSMOW) plotted against $X_{\text {Grs }}$ divided by locality and sample (a-d). Error bars on the symbol represent \pm 1 standard deviation $(\sigma)$ obtained by propagation of the measurement standard error, the error on the mass fractionation correction and the error on the matrix effect correction. e Summary diagram. Coloured arrows with a black stroke indicate the variation in $\delta^{18} \mathrm{O}$ between garnet cores and garnet rims. Thin arrows within the coloured fields showing the $\delta^{18} \mathrm{O}$ of garnet rims represent the trend from the inner to the outer rim, where present. The grey vertical dotted line shows a general compositional boundary between pre-Alpine $L P / H T$ garnet and Alpine HP garnet. Exceptions to this trend are metaquartzite VC10-04 that shows similar grossular content in garnet core and rim2, and micaschist FG1315, for which rim3 has $X_{\mathrm{Grs}}=0.10-0.15$. See text for details

Yttrium content is significantly higher in the large core $(100-350 \mu \mathrm{g} / \mathrm{g})$ with respect to the inner part of the small grains $(\sim 50 \mu \mathrm{g} / \mathrm{g})$, and it is intermediate in the high grossular rims (150-200 $\mu \mathrm{g} / \mathrm{g}$ ) (Fig. 5l).

In summary, unlike the garnet in the eclogites, garnet in the metasediments preserves cross cutting core-rim textures. The porphyroclastic relict cores show resorption features such as lobate structure and cross cutting veinlets. They are characterized by distinct major (most notably low $\mathrm{Ca}$ and high $\mathrm{Mn}$ ) and trace element compositions (in most cases a

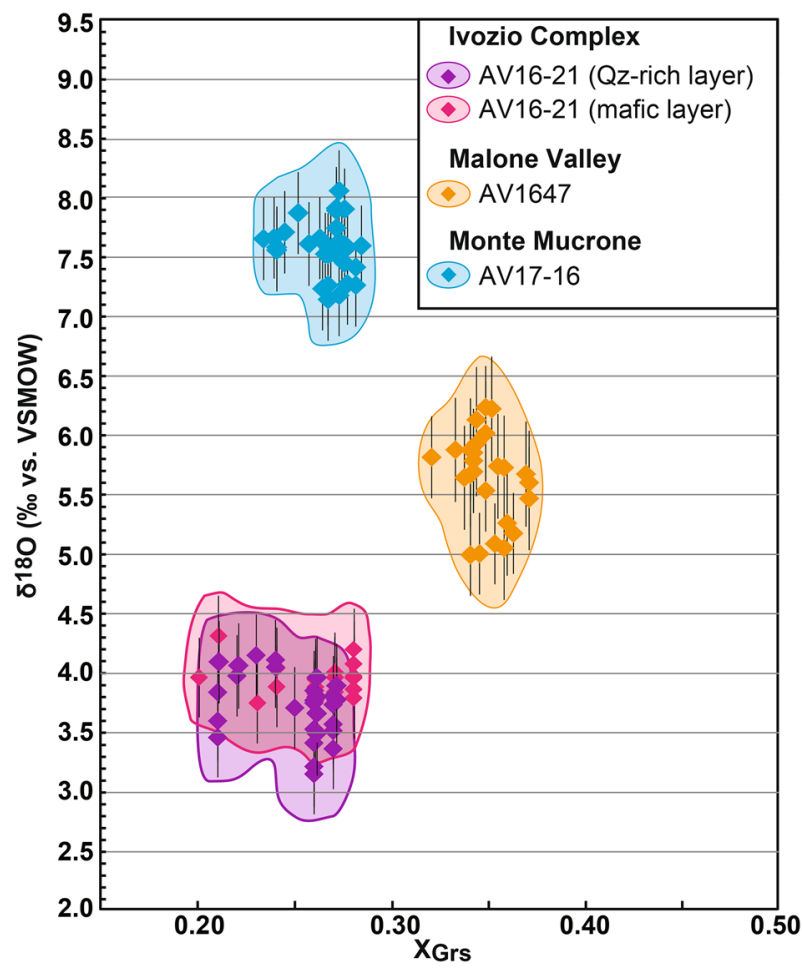

Fig. 6 Oxygen isotope composition of eclogites $\left(\delta^{18} \mathrm{O}\right.$ in $\%$ vs. VSMOW) plotted against $X_{\mathrm{Grs}}$. Error bars on the symbol represent \pm 1 standard deviation $(\sigma)$ obtained by propagation of the measurement standard error, the error on the mass fractionation correction and the error on the matrix effect correction. $\mathrm{Qz}=$ quartz 

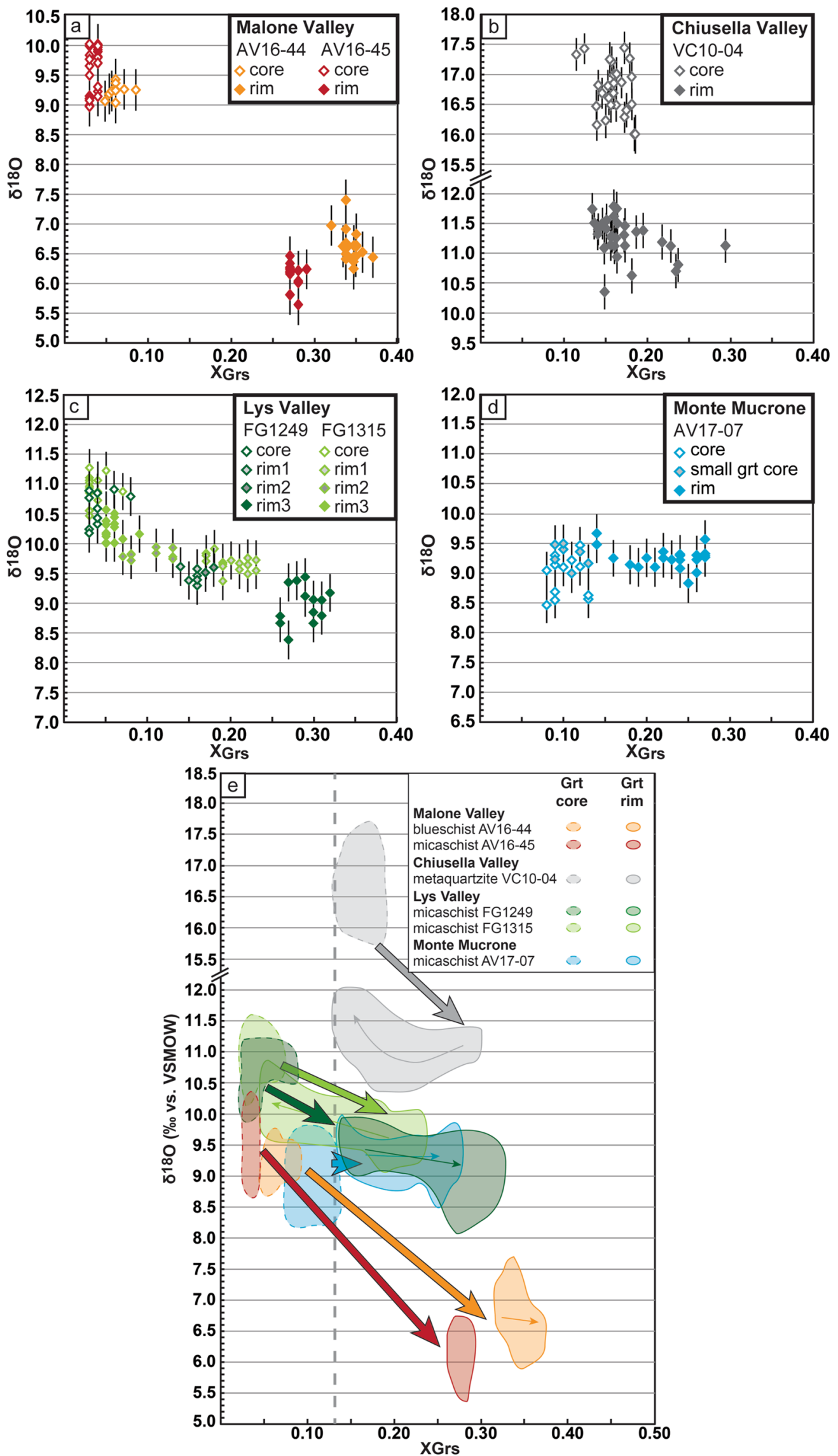
Table 2 Summary of the constraints on the occurrence of fluid pulses based on elemental and oxygen isotope zoning in garnet (Grt)

\begin{tabular}{|c|c|c|c|c|c|c|c|c|}
\hline \multirow[t]{2}{*}{ Sample } & \multirow[t]{2}{*}{ Lithology } & \multirow{2}{*}{$\begin{array}{l}\text { Monocyclic } \\
v s . \text { Polycy- } \\
\text { clic }\end{array}$} & \multirow{2}{*}{$\begin{array}{l}\text { Number of } \\
\text { Alpine Grt } \\
\text { generations }\end{array}$} & \multicolumn{3}{|c|}{$\delta^{18} \mathrm{O}$ Grt $( \pm 2 \mathrm{sd})$} & \multicolumn{2}{|c|}{ Fluid influx(es) } \\
\hline & & & & \multicolumn{2}{|c|}{ Core (pre-Alpine) } & \multirow{2}{*}{$\begin{array}{l}\text { Rim } \\
\text { (Alpine) }\end{array}$} & \multirow{2}{*}{$\begin{array}{l}\text { between pre- } \\
\text { Alpine and } \\
\text { Alpine Grt } \\
\text { growth }\end{array}$} & \multirow{2}{*}{$\begin{array}{l}\text { during Alpine } \\
\text { Grt growth }\end{array}$} \\
\hline \multicolumn{6}{|c|}{ Malone Valley } & & & \\
\hline AV16-44 & Blueschist & $\mathrm{P}$ & 1 & $9.3 \pm 0.6 \%$ & $6.7 \pm 0.6 \%$ & & $\begin{array}{l}\text { External in } \\
\text { isotopic } \\
\text { disequilib- } \\
\text { rium }\end{array}$ & - \\
\hline AV16-45 & Micaschist & $\mathrm{P}$ & 1 & $9.6 \pm 0.8 \%$ & $6.1 \pm 0.4 \%$ & & $\begin{array}{l}\text { External in } \\
\text { isotopic } \\
\text { disequilib- } \\
\text { rium }\end{array}$ & - \\
\hline AV16-47 & Eclogite & M & 1 & - & $5.7 \pm 0.7 \%$ & & - & - \\
\hline \multicolumn{9}{|c|}{ Ivozio Complex } \\
\hline AV16-21 & Eclogite & M & 2 & - & $\begin{array}{l}3.9 \pm 0.4 \% \text { (mafic layer) } \\
3.7 \pm 0.6 \% \text { (Qz-rich layer) }\end{array}$ & & - & $\begin{array}{l}\text { Internal or } \\
\text { external } \\
\text { in isotopic } \\
\text { equilibrium }\end{array}$ \\
\hline \multicolumn{9}{|c|}{ Cima di Bonze } \\
\hline VC10-04 & $\begin{array}{l}\text { metaquartz- } \\
\text { ite }\end{array}$ & $P$ & 2 & $\begin{array}{c}16.6 \pm 1.2 \\
\% 0\end{array}$ & $\begin{array}{l}11.3 \pm 0.7 \% \\
\text { (rim1 and rim2) }\end{array}$ & & $\begin{array}{l}\text { External in } \\
\text { isotopic } \\
\text { disequilib- } \\
\text { rium }\end{array}$ & $\begin{array}{l}\text { Internal or } \\
\text { external } \\
\text { in isotopic } \\
\text { equilibrium }\end{array}$ \\
\hline \multicolumn{9}{|l|}{ Lys Valley } \\
\hline FG1249 & Micaschist & $\mathrm{P}$ & 3 & $\begin{array}{c}10.6 \pm 0.6 \\
\% 0\end{array}$ & $\begin{array}{l}9.5 \pm 0.2 \% \circ(\operatorname{rim} 1) \\
9.5 \pm 0.2 \% \circ(\operatorname{rim} 2) \\
9.0 \pm 0.3 \% \circ(\operatorname{rim} 3)\end{array}$ & & $\begin{array}{l}\text { External in } \\
\text { isotopic } \\
\text { disequilib- } \\
\text { rium }\end{array}$ & $\begin{array}{l}\text { Internal or } \\
\text { external } \\
\text { in isotopic } \\
\text { equilibrium }\end{array}$ \\
\hline FG1315 & Micaschist & $\mathrm{P}$ & 3 & $\begin{array}{c}10.9 \pm 0.6 \\
\% o\end{array}$ & $\begin{array}{l}9.7 \pm 0.2 \% \text { ( } \operatorname{rim} 1) \\
10.2 \pm 0.4 \% \circ(\operatorname{rim} 2) \\
10.2 \pm 0.4 \% \text { (rim3) }\end{array}$ & & $\begin{array}{l}\text { External in } \\
\text { isotopic } \\
\text { disequilib- } \\
\text { rium }\end{array}$ & $\begin{array}{l}\text { Internal or } \\
\text { external } \\
\text { in isotopic } \\
\text { equilibrium }\end{array}$ \\
\hline \multicolumn{9}{|c|}{ Monte Mucrone } \\
\hline AV17-07 & Micaschist & $\mathrm{P}$ & 1 & $9.2 \pm 0.6 \%$ os & $9.2 \pm 0.6 \%$ & & $\begin{array}{l}\text { Internal or } \\
\text { external } \\
\text { in isotopic } \\
\text { equi- } \\
\text { librium } \\
\text { (minor re- } \\
\text { hydration) }\end{array}$ & $\begin{array}{l}\text { Internal or } \\
\text { external } \\
\text { in isotopic } \\
\text { equilibrium }\end{array}$ \\
\hline AV17-16 & Eclogite & M & 2 & - & $\begin{array}{l}7.6 \pm 0.4 \% \\
\text { (Alpine Grt generations } \\
1 \text { and } 2 \text { ) }\end{array}$ & & - & $\begin{array}{l}\text { Internal or } \\
\text { external } \\
\text { in isotopic } \\
\text { equilibrium }\end{array}$ \\
\hline
\end{tabular}

$Q z$ quartz

steeper HREE enrichment, stronger negative Eu and a higher $\mathrm{Y}$ content) with respect to the rims.

\section{Oxygen isotope composition of garnet}

Garnet was analysed for oxygen isotopes in nine samples, including two metasediments from Malone Valley
(AV16-44, AV16-45) and an associated eclogite (AV16-47), the Ivozio Complex eclogite (AV16-21), a Mn-metaquartzite from Chiusella Valley (VC10-04), two micaschists from the Lys Valley (FG1315, FG1249), a micaschist from Monte Mucrone (AV17-07) and an associated eclogite (AV17-16) (Figs. 6, 7). Average $\delta^{18} \mathrm{O}$ values (Table 2) are reported with standard deviation $(2 \sigma)$ uncertainty, and it should be kept in 
mind that when comparing garnet data to other minerals, the accuracy of the garnet $\delta^{18} \mathrm{O}$ is limited by the matrix bias correction, which has a residual of $0.28 \%$ (Vho et al. 2020b). Oxygen isotope analyses are given in Online Resource 7, together with information on the matrix correction and the secondary reference material.

\section{Eclogites}

Garnet in eclogites from three different localities has distinct oxygen isotopic composition (Fig. 6), but no internal zoning. Values of $\delta^{18} \mathrm{O}$ in the garnet of the eclogite AV16-47 from Malone Valley were measured across three grains. Measured $\delta^{18} \mathrm{O}$ values show no clear trend from core to rim with an average of $5.7 \pm 0.7 \%$. The oxygen isotope composition of the two types of garnet from the Ivozio Complex metagabbro (sample AV16-21) was analysed. The large garnet within a domain rich in quartz and white mica has a $\delta^{18} \mathrm{O}$ of $3.7 \pm 0.6$ $\% o$ and the small garnet in the mafic domain has a $\delta^{18} \mathrm{O}$ of $3.9 \pm 0.4 \%$. No significant variation in $\delta^{18} \mathrm{O}$ from core to rim was observed (Fig. 6). Traverses across two garnet grains from the eclogite vein AV17-16 from Monte Mucrone show no zoning and yield and average $\delta^{18} \mathrm{O}$ of $7.6 \pm 0.4 \%$ 。 (Fig. 6).

\section{Metasediments}

In the metasediments, variable decreases in $\delta^{18} \mathrm{O}$ from the low-Ca core to the rim are observed (Fig. 7, Table 2, Online Resource 7). The $\delta^{18} \mathrm{O}$ values in garnet from the Malone Valley blueschist AV16-44 decrease of $\sim 2.5 \%$ o from core $(9.3 \pm 0.6 \%$ ) to rim $(6.7 \pm 0.6 \%)$. In the garnet from the micaschist AV16-45 a maximum decrease in $\delta^{18} \mathrm{O}$ of $\sim 3.5 \%$ was measured between the high $\delta^{18} \mathrm{O}$ core $(9.6 \pm 0.8 \% o)$ and the low $\delta^{18} \mathrm{O} \operatorname{rim}(6.1 \pm 0.4 \%)$. In the garnet from the metaquartzite VC10-04 from Chiusella Valley, the $\delta^{18} \mathrm{O}$ decreases drastically from the core $(16.7 \pm 0.9$ $\%$ o) to the rims $(11.3 \pm 0.7 \%$ o). Garnet FG1249 has a core $\delta^{18} \mathrm{O}=10.6 \pm 0.6 \%$, a rim 1 and $\operatorname{rim} 2 \delta^{18} \mathrm{O}=9.5 \pm 0.2$ $\%$, and outer rim $3 \delta^{18} \mathrm{O}=9.0 \pm 0.6 \%$. Garnet FG1315 has a core $\delta^{18} \mathrm{O}$ of $10.9 \pm 0.4 \%$, whereas the $\delta^{18} \mathrm{O}$ in the high-grossular rim 1 is $9.7 \pm 0.2 \%$ and it remains within uncertainty the same in $\operatorname{rim} 2$ and $\operatorname{rim} 3(10.2 \pm 0.4 \%$ o). The micaschist AV17-07 from Monte Mucrone is the only sample where there is no significant variation in $\delta^{18} \mathrm{O}$ among different garnet zones (average $\delta^{18} \mathrm{O}=9.2 \pm 0.6 \%$ ). Notably, in the localities where both metasediments and eclogites were investigated, the $\delta^{18} \mathrm{O}$ composition of the garnet rim in the metasediment is comparable to that of the garnet in the nearby eclogite (Table 2).

\section{Oxygen isotope composition of other phases}

The oxygen isotopic composition was measured in other phases to detect if they also preserve $\delta^{18} \mathrm{O}$ zoning and if they were in isotopic equilibrium with garnet. $\delta^{18} \mathrm{O}$ values were measured in quartz and phengite from the micaschist AV1645 from Malone Valley, and in phengite in the micaschist AV17-07 as well as in the eclogite AV17-16 from Monte Mucrone (Fig. 8).

In micaschist AV16-45, garnet $\delta^{18} \mathrm{O}$ varies significantly from core to rim. Quartz isotopic composition is homogeneous with $\delta^{18} \mathrm{O}=12.6 \pm 0.3 \%$ ( $\left.2 \sigma\right)$ regardless the microstructural position (i.e. inclusion in garnet, garnet pressure shadow or quartz ribbons in the main foliation). Phengite in the foliation has also homogeneous $\delta^{18} \mathrm{O}=8.6 \pm 0.6 \%$. In micaschist AV17-07, large phengite flakes found in the atoll-forming garnet and in the matrix have similar isotopic composition $(10.0 \pm 0.4 \%$ ). In the associate eclogite AV1716 , phengite grains both included in garnet and in the matrix have $\delta^{18} \mathrm{O}=10.3 \pm 0.4 \%$.

Oxygen isotope compositions of quartz from different microstructural domains in micaschists FG1249 and FG1315 from Lys Valley are given in Engi et al. (2018). Micaschist FG1249 shows a $\delta^{18} \mathrm{O}$ of $13.6 \pm 0.4 \%$ in the quartz relics preserved inside garnet porphyroclasts and in old quartz bands, and a $\delta^{18} \mathrm{O}$ of $13.9 \pm 0.4 \%$ in the matrix quartz. Micaschist FG1315 shows a $\delta^{18} \mathrm{O}$ for the quartz relics preserved inside garnet porphyroclasts and in old quartz bands of $15.0 \pm 0.3 \%$, for the matrix quartz of $14.6 \pm 0.5 \%$ and for the quartz located in the atoll garnet of $14.3 \pm 0.8 \%$.

\section{Discussion}

\section{Multiple garnet growth stages reconstructed from element zoning}

Garnet in the eclogite samples (AV16-47, AV16-21 and AV17-16) shows a continuous growth zoning, except for secondary veinlets in samples AV16-21 and AV17-16. By contrast, garnet in the metasediments preserves a porphyroclastic core surrounded by one or more rim generations. Garnet cores typically show resorption features such as lobate structure and evidence for brittle deformation such as veinlet networks. In most cases, the relict garnet cores are lower in $X_{\mathrm{Grs}}$ and higher in $X_{\mathrm{Sps}}$ than the surrounding rims (Fig. 4). Metaquartzite VC10-04 is an exception to the $X_{\text {Grs }}$ trend, but this is likely due to the overall low Ca content in this rock type. Complex garnets have been extensively investigated in micaschists FG1249 and FG1315 by Giuntoli et al. (2018b) based on their major element composition. The porphyroclastic cores were interpreted as relics of garnet stable at granulite facies conditions correlated to 


\section{MALONE VALLEY - micaschist AV16-45}

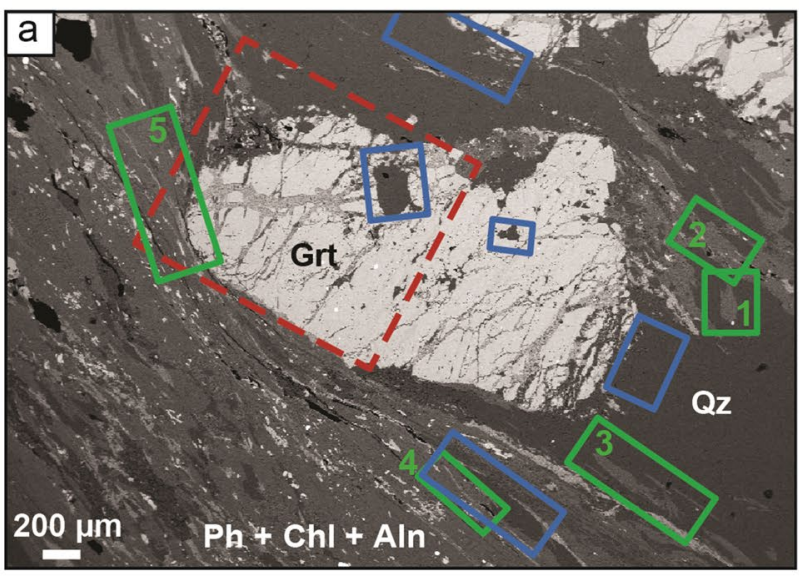

MONTE MUCRONE - eclogite AV17-16
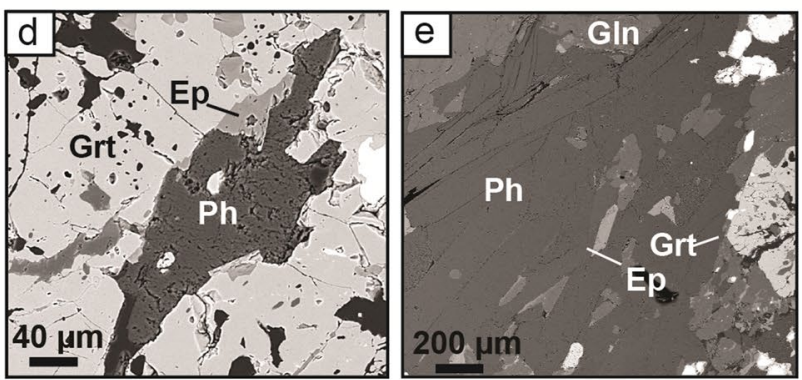

\section{MONTE MUCRONE - micaschist AV17-07}
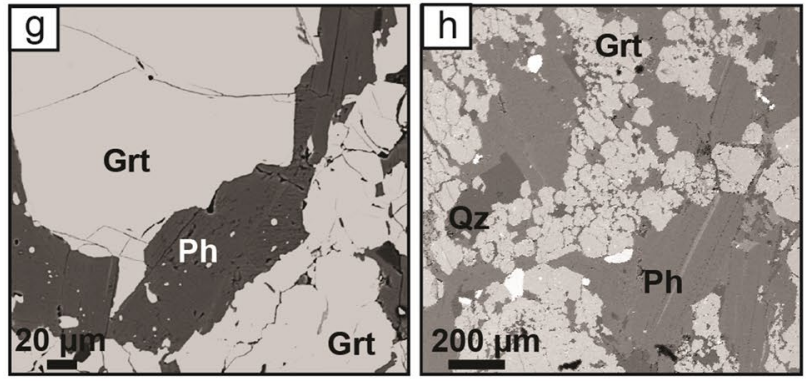

Fig. 8 Oxygen isotope composition of quartz and phengite $\left(\delta^{18} \mathrm{O}\right.$ in $\%$ vs. VSMOW). a BSE image of blueschist AV16-44 (Malone Valley). The garnet grain in the centre is the same analysed for major and trace elements, as well as oxygen isotopes (area marked by the red dashed line). Blue rectangles mark the domains where quartz was analysed for oxygen isotopes (in the proximity of the garnet rim, in the pressure shadow and in the foliation). Green rectangles mark the domains where phengite was analysed for oxygen isotopes. $\mathbf{b}, \mathbf{c}$ Oxygen isotope composition of quartz and phengite, respectively, in micaschist AV16-45 (Malone Valley). d, e BSE images of analysed phengite in eclogite AV17-16 (Monte Mucrone) as inclusion in garnet

the early Permian high temperature/low pressure (HT/LP) metamorphism (Lanari et al. 2017; Giuntoli et al. 2018a, b; Kunz et al. 2018). A similar early Permian metamorphic
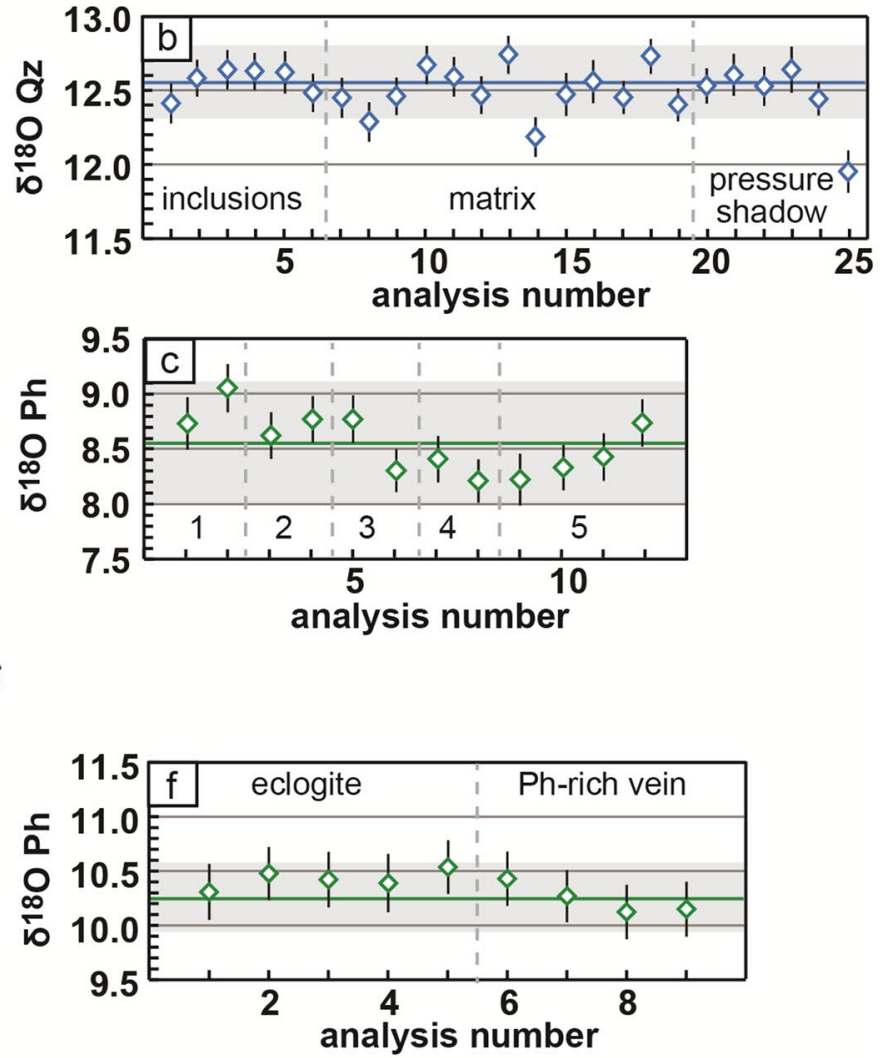

and in the phengite-rich veins, respectively. f Oxygen isotope composition of phengite in sample AV17-16. $\mathbf{g}$, $\mathbf{h}$ BSE images of analysed phengite within atoll garnet from micaschist AV17-07 (Monte Mucrone). f Oxygen isotope composition of phengite in micaschist AV17-07. Error bars on the symbol represent \pm 1 se obtained by propagation of the measurement standard error and the error on the mass fractionation correction. Coloured horizontal lines mark the average value of isotopically homogenous zones and the associated grey fields represents $\pm 2 \sigma$ on the average. Mineral abbreviations are from Whitney and Evans (2010)

stage characterized by HT/LP conditions has been proposed also for the area of Monte Mucrone (Rubatto et al. 1999; Zucali et al. 2002; Cenki-Tok et al. 2011; Kunz et al. 2018), 
for Malone Valley and likely occurred also in the Chiusella Valley. Therefore, garnet cores in the metasediments from all localities are interpreted as relics of garnet grown at granulite facies conditions, likely during the late Permian HT/ LP metamorphic stage and are referred to as "pre-Alpine" garnet.

Garnet rims overgrowing the relict cores are related to HP metamorphism during the Alpine evolution and they are referred to as "Alpine" garnet. Garnet rim1 in micaschist FG1249 was correlated by Giuntoli et al. (2018b) to a preAlpine amphibolite facies metamorphism that followed the granulite facies stage on the base of thermodynamic modelling. However, the affinity of major and trace element characteristics with the other Alpine rims (Fig. 5) favour the re-interpretation that rim1 represents the first Alpine rim in this sample.

Trace elements zoning can provide further insights into the processes that controlled the major element zonation, such as nucleation, equilibrium growth, element transport and diffusion, and reveal additional processes that influenced garnet growth, such as episodic breakdown of other phases, inheritances from precursor phases and selective replacement (e.g. George et al. 2018; Rubatto et al. 2020). Different types of trace element zoning can be recognised in the analysed samples.

(1) Pre-Alpine cores typically show a negative Eu anomaly, while Alpine garnet generations have $\mathrm{Eu} / \mathrm{Eu}^{*}$ values close to 1 in both the eclogites (Fig. 3) and the metasediments (Fig. 5). The change in Eu anomaly is compatible with the presence of a feldspar-bearing assemblage during pre-Alpine HT garnet growth and the lack of feldspar during Alpine eclogite-facies metamorphism (Rubatto 2002).

(2) Sharp changes in Y + HREE between pre-Alpine cores and Alpine rims occur in metaquartzite VC1004 (Chiusella Valley) and in micaschist FG1249 (Lys Valley) (Fig. 5). In these samples, the abrupt decrease in $\mathrm{Y}+\mathrm{HREE}$ between the pre-Alpine cores and the Alpine rims is attributed to $\mathrm{Y}+\mathrm{HREE}$ sequestration in the relict garnet core and substantial new growth of garnet (controlled by major element availability and $P-T$ ) during Alpine metamorphism, without any other phases releasing significant amounts of these trace elements in the reactive bulk composition. On the contrary, in micaschist FG1315 from the Lys Valley, garnet rim1 shows strongly variable $\mathrm{Y}+\mathrm{HREE}$ patterns, enriched in trace elements with respect to the pre-Alpine core. This might be caused by concomitant processes, including resorption of a larger fraction of garnet than that growing at HP conditions and breakdown of other M-HREE hosting phases such as monazite, xenotime, titanite or allanite.
(3) No sharp changes, but only a slight decrease in $\mathrm{Y}+\mathrm{HREE}$ content between the pre-Alpine core and the Alpine rim is observed in metasediments AV1644 and AV16-45 from Malone Valley (Fig. 5), despite the large changes in major element composition and $\delta^{18} \mathrm{O}$ value. This indicates that external fluids do not necessarily transport $\mathrm{Y}+\mathrm{HREE}$ (Hermann and Rubatto 2009), whereas they can strongly affect the bulk $\delta^{18} \mathrm{O}$ (e.g. Vho et al. 2020a).

(4) Variations in REE patterns among Alpine garnet zones are mainly due to changes in MREE content, but an associated enrichment in $\mathrm{Y}$ is observed in the eclogite AV17-16 from Monte Mucrone and in the rim of the garnet AV16-21 from the quartz-rich layer from the Ivozio Complex eclogite (Fig. 3). Garnet resorption is a potential source of $\mathrm{Y}$, but it would also release HREE and Mn. While this might be the case for the rim of garnet AV17-16, in garnet AV16-21 the euhedral shape of the grain and the lack of any Mn enrichment in the rim exclude garnet resorption. In this sample, such variations are likely due to breakdown of other phases such as titanite and lawsonite during prograde Alpine metamorphism. The latter has the potential to release not only a significant amount of the REE and Y (e.g. Martin et al. 2014a; Vitale Brovarone et al. 2014) that are enriched in the garnet rims described above, but also 11.5 wt \% of $\mathrm{H}_{2} \mathrm{O}$ that might contribute to an internally buffered re-hydration of the host rock at HP conditions (e.g. Vitale Brovarone and Beyssac 2014) and promote garnet replacement via interface-coupled dissolution-precipitation. In the Ivozio Complex lawsonite pseudomorphs are abundant and lawsonite breakdown likely occurred between the growth of the garnet mantle and rim (Zucali et al. 2004).

(5) A trend of decreasing $\mathrm{Lu}_{\mathrm{N}} / \mathrm{Dy}_{\mathrm{N}}$ and $\mathrm{Y}+\mathrm{HREE}$ content from core to rim is observed in the eclogites AV16-47 from Malone Valley and AV16-21 from Ivozio Complex, with the exception of the rim of garnet AV16-21 from the quartz-rich layer that shows an increase in Y + HREE (Fig. 3). Such a continuous decrease can be attributed to Rayleigh-type fractionation between the growing garnet and the mineral matrix.

\section{Constraints on fluid influx}

It has been proposed that in the SZ the re-hydration of the pre-Alpine $H T$ assemblages by external fluids is a necessary condition in order to extensively re-equilibrate them at blueschist/eclogite facies conditions and grow Alpine garnet from assemblages that contained hydrous phases (Compagnoni 1977; Pognante 1989a; Konrad-Schmolke et al. 2006; Engi et al. 2018; Giuntoli et al. 2018b). It has also been proposed that further water influx is required along the entire 
prograde $P-T$ path to impose water saturation (KonradSchmolke et al. 2006). Fluid-driven re-equilibration during the retrograde evolution has additionally been recognized in the EMC (Babist et al. 2006; Konrad-Schmolke et al. 2011a, b; Giuntoli and Engi 2016). Since the focus of this study is on the rehydration occurring from pre-subduction to peak conditions, the retrograde stages will not be discussed in detail. In the following, we discuss the constraints on the conditions at which these events of fluid influx occurred. A summary to guide the discussion is shown in Table 2.

Assuming a dry crust model (Yardley and Valley 1997), mineral-fluid interaction requires addition of fluid from an external source, referred to as fluid input in the following. Garnet textures that are considered indicative of mineral-fluid interaction include: (1) the irregular shape of pre-Alpine garnet cores with embayment features in the metasediments (metasediments AV16-44 and AV1645, metaquartzite VC10-04, and micaschists FG1249 and FG1315; Fig. 4), (2) atoll and mushroom textures (metaquartzite VC10-04; Fig. 4) and (3) secondary veinlets of different composition in pre-Alpine garnet cores in the metasediments (FG1249 and FG1315; Fig. 4) and in the Alpine garnet in eclogites (AV16-21 and AV17-16; Fig. 2). Core resorption and veinlets cross cutting the cores are sealed by the growth of the rim and thus are attributed to fluid inputs that occurred after pre-Alpine garnet growth and before-or in correspondence to- the growth of Alpine rims. Atoll textures and secondary veinlets in garnet rims must necessarily postdate Alpine garnet growth.

\section{Permian to early Alpine input of external fluids}

Granulite facies rocks in which the low-Ca, pre-Alpine garnet cores crystallized are expected to contain low amounts of water (i.e. <0.5 wt\%; Engi et al. 2018). The earliest possible stage for resorption of pre-Alpine garnet and crosscutting veinlets is a re-hydration at amphibolite facies conditions during the retrograde Permian metamorphism that has been recognized in different areas of the SZ (e.g. Lardeaux et al. 1982; Lardeaux and Spalla 1991; Rebay and Spalla 2001; Giuntoli et al. 2018b). In micaschists from Lys Valley, the presence of veinlets was interpreted as a result of seismic failure that occurred during subduction, and that facilitated fluid access-the fractures were sealed by garnet having the same composition as the first rim generation (Engi et al. 2018; Giuntoli et al. 2018b).

In the investigated metasediments, the first stage of Alpine garnet growth follows-after a temporal gap-the dissolution of the pre-Alpine cores due to the interaction with a hydrous fluid. At Monte Mucrone, re-hydration was not as pervasive as in the other investigated localities and abundant textural and mineralogical relics of $H T /$ $L P$ metamorphism are still preserved (Oberhänsli et al.
1985; Zucali et al. 2002; Corti et al. 2019). The first Alpine garnet generation grew at different $P-T$ conditions from blueschist to eclogite facies in different areas and different lithologies, from $T=370-450{ }^{\circ} \mathrm{C}$ and $P=1.1-1.3 \mathrm{GPa}$ in the Southern Sesia-Malone Valley area and in the Ivozio Complex (Pognante 1989b; Zucali et al. 2004; Zucali and Spalla 2011), to $T=470-550{ }^{\circ} \mathrm{C}$ and $P=1.2-2.0 \mathrm{GPa}$ for the Monte Mucrone-Mombarone and Chiusella Valley areas (Zucali et al. 2002; Konrad-Schmolke et al. 2011a; Regis et al. 2014; Delleani et al. 2018), and up to $T=600-650{ }^{\circ} \mathrm{C}$ and $P=1.5-1.6 \mathrm{GPa}$ for the Central Sesia-Lys Valley area (Giuntoli et al. 2018b) (Fig. 9). Mineral parageneses in equilibrium with Alpine garnet include various hydrous minerals, i.e. amphibole, zoisite, phengite and minor allanite. In the Ivozio Complex metagabbro, prograde lawsonite is an additional indicator of the presence of a hydrous assemblage already during the early stages of subduction.

A significant difference in oxygen isotope composition between the pre-Alpine garnet cores and the Alpine rims in metasediments from Malone Valley, Chiusella Valley and Lys Valley provides strong evidence for the infiltration of an external fluid (Fig. 7). This fluid must have been in isotopic disequilibrium with the rocks to produce the observed shifts in $\delta^{18} \mathrm{O}$. On the other hand, in the micaschist AV17-07 from Monte Mucrone, the lack of $\delta^{18} \mathrm{O}$ variations in garnet showing resorbed relict cores and multiples rims indicates the absence of significant isotopic disequilibrium between an entering fluid and the rock.

Quartz is another key mineral that was present in the preAlpine mineral assemblages as well as in the HP assemblages. Quartz in the micaschist AV16-45 from Malone Valley shows no variation in oxygen isotope composition (Fig. 8), suggesting that it might have been fully re-equilibrated at HP conditions. Quartz $\delta^{18} \mathrm{O}$ from the Lys Valley micaschists investigated by Engi et al. (2018) shows an increase of $1 \%$ in $\delta^{18} \mathrm{O}$ between quartz included in the garnet cores and matrix quartz in micaschist FG1249 and a decrease up to $2 \%$ in micaschist FG1315 for the same microstructural sites. These shifts in $\delta 180$ are attributed by the authors to the influx of an external fluid with $\delta^{18} \mathrm{O}$ of $\sim 14$ $\%$. However, previous studies (e.g. Kohn 1993; Vho et al. 2020a) showed that quartz is one of the most sensitive minerals to temperature variation and its oxygen isotope composition can vary up to $1-2 \%$ over a temperature variation of $100{ }^{\circ} \mathrm{C}$, without external fluid input. Therefore, we conclude that garnet is a better tracer of fluid-rock interaction with respect to quartz, because of its retentivity of primary zoning, robustness to recrystallization (and thus resetting of isotopic systems) and only minor $\delta^{18} \mathrm{O}$ variations in a closed system. 


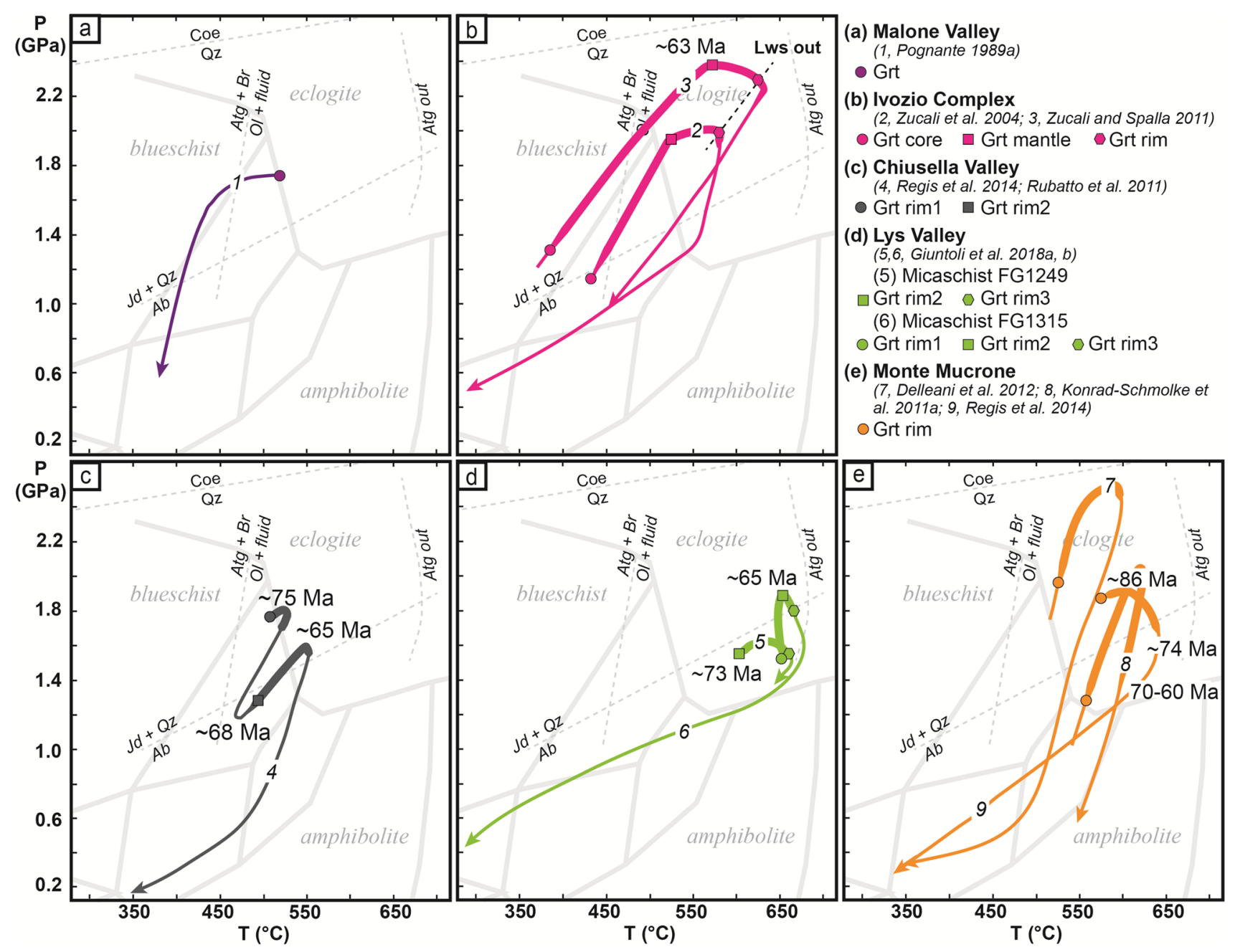

Fig. $9 P-T$ paths of the rocks from the investigated localities taken from the literature and available time constraints on HP metamorphism (Pognante 1989b; Zucali et al. 2004; Konrad-Schmolke et al. 2011a; Rubatto et al. 2011; Zucali and Spalla 2011; Delleani et al.

\section{Fluid events during Alpine garnet formation}

Two types of textures marked by major and trace element variations that are not related to continuous growth zoning are recognized in Alpine garnet from several samples: (1) secondary radial veinlets and (2) cross cutting garnet rims within single samples.

The veinlets that propagate to the interior of the garnet in eclogites AV16-21 and AV17-16 (Online Resource 3) are attributed to fluid-driven replacement during Alpine HP metamorphism, as their composition is comparable to that of the external garnet rim. In our samples, the absence of significant variation in $\delta^{18} \mathrm{O}$ among veinlets and surrounding garnet indicate that the veinlets might be related to an internal fluid - or external, but in isotopic equilibriumat HP. Comparable radial features have been described in other metamorphic terranes (i.e. Bergen Arcs, Erambert and
2012; Regis et al. 2014; Giuntoli et al. 2018a, b. Coloured symbols represent the inferred conditions of Alpine garnet growth. Thick lines represent continuous growth of garnet along the $P-T$ path

Austrheim 1993; Tauren Window, Kurz et al. 1998; Trescolmen area, Zack et al. 2002). They are consistently interpreted as annealed cracks formed as consequence of fluid input either under eclogite facies conditions or postdating the last garnet rim generation. High spatial resolution trace elements maps of garnet AV16-21 are reported in Rubatto et al. (2020): the veinlets visible in $\mathrm{Mn}$ and $\mathrm{Mg}$ maps only affect the divalent cations $\mathrm{Co}$ and $\mathrm{Zn}$, while there is no correlation with other trace elements. Thus, these veinlets do not represent a crack-sealing mechanism, but are rather related to a selective replacement process (Rubatto et al. 2020).

In these eclogite samples, the enrichment of $\mathrm{Y}+\mathrm{REE}$ in the garnet external rim with respect to the mantle demands a strong and sustained replenishment of trace elements in the reactive bulk composition during the growth of garnet rim (Fig. 3). An input of TE-rich external fluids, as for example from the surrounding metasediments, might produce such 
$\mathrm{Y}+\mathrm{REE}$ enrichment. However, in the Ivozio Complex this hypothesis is in contrast with the low and constant $\delta^{18} \mathrm{O}$ values in garnet. Alternatively, $\mathrm{Y}+\mathrm{REE}$ enriched garnet rim could result from lawsonite breakdown, as lawsonite pseudomorphs are abundant in the Ivozio Complex (Zucali et al. 2004). In eclogite AV17-16 from Monte Mucrone, another evidence of fluid inputs(s) at HP is the presence of texturally late, phengite-glaucophane-garnet veins (Figs. S1-8e-f). In both the eclogite and the micaschist from this locality, no significant variation in $\delta^{18} \mathrm{O}$ within the garnet (Fig. 7) and the phengite (Fig. 8) was detected. This suggests that the late HP infiltrating fluid had no significant difference in oxygen isotope composition with respect to the rock.

Multiple generations of Alpine garnet in metasediments FG1249 and FG1315 can be distinguished on the base of both major and trace elements (Fig. 4). Giuntoli et al. (2018b) related these rims to subsequent fluid influx events occurring at HP, based on resorption textures, garnet chemical composition and thermodynamic modelling. Our data show that $\mathrm{Y}+\mathrm{HREE}$, which are highly compatible in garnet, mildly increase in content from garnet core to rim2 in FG1249 and to rim1 in FG1315, possibly indicating dissolution of a larger amount of garnet than what was re-precipitated in the following stage. An increase in MREE between different garnet rims can be related to the breakdown of a matrix phase (i.e. monazite, allanite, titanite). Variations in $\delta^{18} \mathrm{O}$ composition among different garnet rims in these samples are within $1 \%$. Such small shifts can be caused by variations in temperature and mineral assemblage, indicating that the fluid infiltrating at HP did not significantly modify the oxygen isotope bulk composition of the rock.

Multiple Alpine rims are also observed in garnet from the metaquartzite VC10-04 from Chiusella Valley. The complex texture is similar to the mushroom and atoll garnet from quartz-rich layers described in the Monte Mucrone area by Robyr et al. (2013). They concluded that an increase of the solubility of quartz in the presence alkali-rich HP fluids caused the precipitation of the garnet rim within the core. In metaquartzite $\mathrm{VC10-04,} \mathrm{no} \mathrm{significant} \mathrm{trace} \mathrm{element} \mathrm{vari-}$ ation is observed among garnet rims (Fig. 5), suggesting no significant release/uptake of trace elements due to breakdown or crystallization of other phases. As already described for samples FG1249 and FG1315 from Lys Valley, no variation in $\delta^{18} \mathrm{O}$ within Alpine garnet rim is observed either (Fig. 7), suggesting that any fluid input during garnet rim formation must be related either to an internal fluid or to an external fluid in isotopic equilibrium with the rock.

To summarize, Alpine garnet in most samples show fluidrelated textures that are marked by compositional differences in major elements and, in several samples, also in $\mathrm{Y}+\mathrm{REE}$. However, no significant variation in $\delta^{18} \mathrm{O}$ among the different Alpine garnet zones has been observed, in contrast to the variation in $\delta^{18} \mathrm{O}$ that occurs in most metasediments between
pre-Alpine garnet cores and Alpine rims. This indicates that any fluid producing the Alpine rims was either internally produced (thus in isotopic equilibrium with the equilibrium assemblage) or externally derived, but in apparent isotopic equilibrium with the rock. Because Alpine garnet growth initiated at different $P-T$ conditions in different rock types, episodes of fluid inputs cannot necessarily be correlated across localities and the age of fluid-rock interaction varies from slice to slice.

\section{Potential sources of fluids and implications for fluid pathways}

Variable shifts of $\delta^{18} \mathrm{O}$ values are observed between HT preAlpine garnet core and HP Alpine garnet rims in metasediments. While any change in temperature and stable mineral assemblage potentially drives shifts in the $\delta^{18} \mathrm{O}$ of garnet, variations larger than $\sim 1 \%$ o have to be attributed to a significant change in bulk $\delta^{18} \mathrm{O}$ composition, most likely occurring as consequence of interaction with an external fluid of different isotopic composition (Kohn 1993; Vho et al. 2020a). As discussed above, several rocks in the SZ show clear evidence for interaction with external fluids in isotopic disequilibrium between the pre-Alpine and the Alpine garnet growth. Calculations reported in Online Resource 4 were made to simulate a closed system evolution of key samples (metaquartzite VC10-04, micaschists AV16-45, FG1245 and FG1315) from a modelled HT pre-Alpine assemblage to the Alpine HP assemblage. Maintaining a constant bulk $\delta^{18} \mathrm{O}$, and considering changes in temperature, mineral assemblage and modal proportions between the two stages, the calculations show that garnet core to rim (pre-Alpine to Alpine) variation in $\delta^{18} \mathrm{O}$ in a closed system should be between 0.9 and $1.8 \%$. This is in contrast with the variation in $\delta^{18} \mathrm{O}$ of 2.9-5.3\% measured in sample VC10-04, AV16-45 and AV16-44 between garnet core and rim (Fig. 7, Table 2).

Whereas there are significant differences between the $\delta^{18} \mathrm{O}$ of Alpine garnet in the different localities, the similarity in $\delta^{18} \mathrm{O}$ composition in Alpine garnet between metasediments and eclogites in the same outcrop at Malone Valley and Monte Mucrone is surprising. The two rock types have different sources (sedimentary versus mafic melts) and are expected to have relatively high and low $\delta^{18} \mathrm{O}$ bulk rock values (10-18\%o versus 5-7\%o). Internal mineral fractionation cannot compensate for the lack of difference in the garnet $\delta^{18} \mathrm{O}$. The unexpectedly high $\delta^{18} \mathrm{O}>7 \%$ of garnet in the eclogite boudins with metasediments suggests a pervasive homogenization of oxygen isotopic compositions at the outcrop scale (10-100 m) in each locality, before or during subduction.

During the tectonic evolution of the SZ, two scenarios are suitable for an extensive re-hydration by external fluids with low $\delta^{18} \mathrm{O}$ : (1) interaction with seawater during crustal 
extension in a pre-subduction setting and (2) interaction with fluids deriving from dehydration reactions during subduction from rocks that were hydrated at the sea-floor during rifting.

\section{Re-hydration by sea-floor alteration during extension}

It has been proposed that during Jurassic rifting, the SZ formed extensional allochthons in the distal part of the Adriatic margin (e.g. Dal Piaz et al. 2001; Babist et al. 2006). This tectonic setting would be prone to oceanic alteration and thus localised intense re-hydration of the HT metamorphic basement constituting the SZ. Exposure at the sea-floor from the Triassic until the subduction in the Cretaceous is indicated firstly by the presence of Mesozoic sediments deposited onto thinned, pre-Mesozoic lower continental crust (Venturini et al. 1994; Regis et al. 2015; Giuntoli and Engi 2016) and secondly by the local presence of rodingites (Ferraris and Compagnoni 2003). During rifting, marine water represents a source of fluid with constant, low $\delta^{18} \mathrm{O}$ of $\sim 0 \%$. As analogue, in the non-subducted Adriatic distal margin of the Platta nappe (oceanic domain) and Err nappe (continental domain) extensional structures are preserved and strong evidence for hydrothermal fluid circulation during rifting has been recognized along fault zones (Manatschal et al. 2000; Pinto et al. 2015; Incerpi et al. 2017). For the
Platta and Err nappes, hydrothermal alteration by seawater that first interacted with the subcontinental mantle, leading to serpentinization, and subsequently migrated upward, was proposed by Manatschal et al. (2000) and Pinto et al. (2015) (Fig. 10). Oxygen isotope analysis of massive serpentinites in the Platta nappe (Früh-Green et al. 1990) yielded a $\delta^{18} \mathrm{O}$ of 8.4-9.7\%o, corresponding to a temperature of $\sim 100{ }^{\circ} \mathrm{C}$ $( \pm 30,2 \sigma)$ for the interaction between rock and seawater with a $\delta^{18} \mathrm{O}$ of $0 \%$ (oxygen isotope fractionation factors taken from Vho et al. 2019). Any isotopic exchange between infiltrating seawater and crustal rocks (i.e. Err nappe) would modify the isotopic composition of the infiltrating seawater toward higher $\delta^{18} \mathrm{O}$, affecting the calculation of the temperature of interaction.

Interaction of the SZ basement rocks (mostly composed by granulite and amphibolite facies metasediments) with seawater at $150{ }^{\circ} \mathrm{C}$ would produce alteration of primary $\mathrm{HT}$ feldspar $\left(\delta^{18} \mathrm{O} \approx 12 \%\right.$ ) , sillimanite $\left(\delta^{18} \mathrm{O} \approx 12 \%\right.$ ), biotite $\left(\delta^{18} \mathrm{O} \approx 10 \%\right.$ ) and garnet $\left(\delta^{18} \mathrm{O} \approx 10.0 \%\right.$ ) and recrystallization to an assemblage containing chlorite $\left(\delta^{18} \mathrm{O} \approx 5.0 \%\right.$ ), illite $\left(\delta^{18} \mathrm{O} \approx 10.0 \%\right.$ ) and epidote $\left(\delta^{18} \mathrm{O} \approx 8.5 \%\right.$ ) (oxygen isotope fractionation factors taken from Vho et al. 2019), leading to an overall decrease in bulk $\delta^{18} \mathrm{O}$ of the altered rock. Interaction with low- $\delta{ }^{18} \mathrm{O}$ sea-derived water, infiltrating from the sea floor or flowing from the exhuming mantle
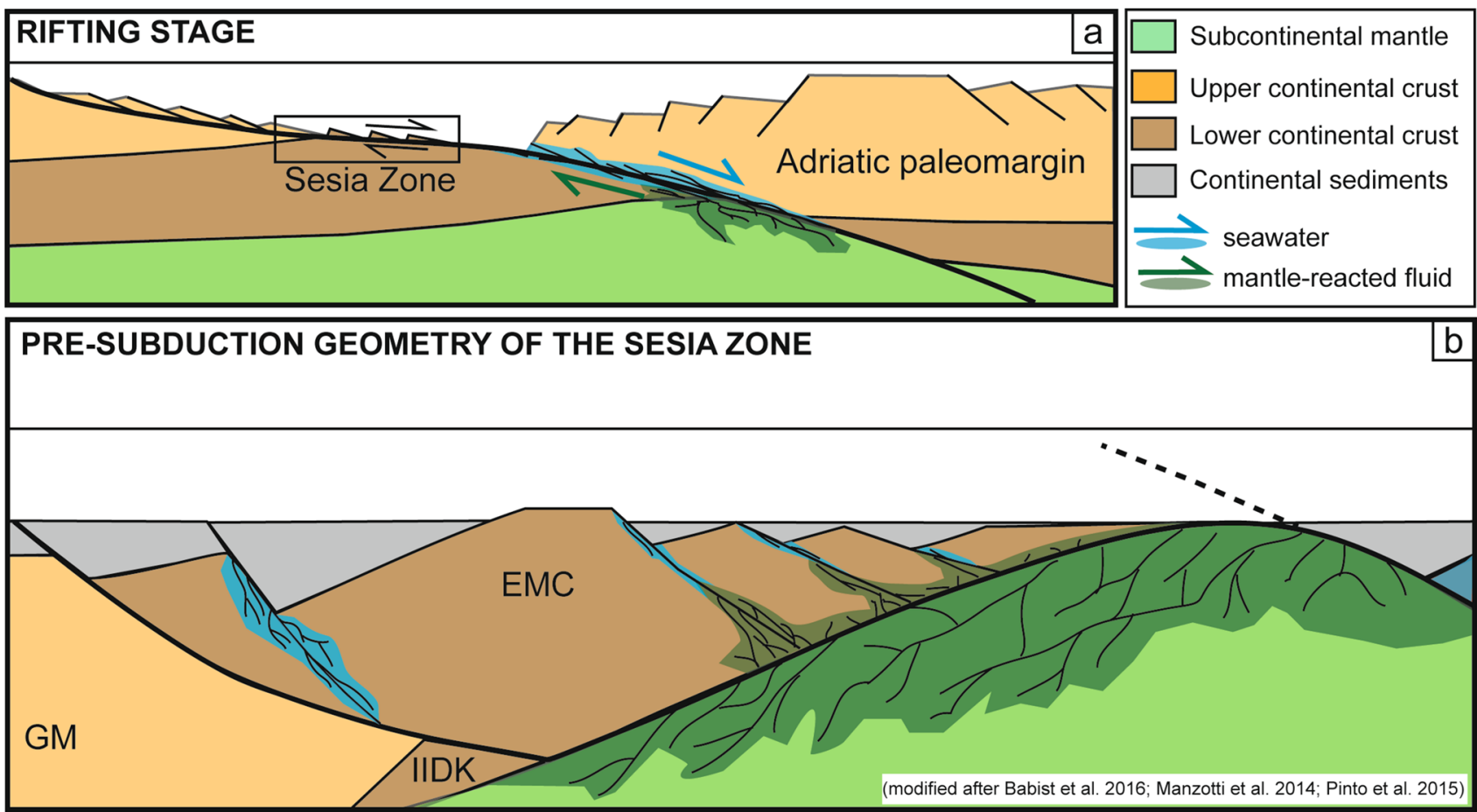

Fig. 10 Tectonic reconstruction of the paleo-Adriatic margin a during rifting and $\mathbf{b}$ in the pre-subduction geometry (after Babist et al. 2006; Manzotti et al. 2014; Pinto et al. 2015). Infiltration of seawater (blue shaded area) occurs along major shear zones during rifting, reaches the subcontinental mantle (green shaded area), heats up and infiltrated the overlying crust along extensional faults. EMC $=$ Eclogitic Micaschist Complex; GM=Gneiss Minuti; IIDK=Second DioriticKinzigitic Zone 
through detachment faults (Fig. 10), represents a feasible hypothesis for part of the SZ re-hydration since (1) there is evidence that some portion of the SZ were exposed at the sea-floor and (2) it represents a fluid buffered system where a high fluid/rock ratio and a low $\delta^{18} \mathrm{O}$ of the fluid can be maintained over millions of years. Hydration of the base of the continental crust during exhumation along lithospherescale shear zones have been proposed also for the lowercrustal granulites of the Malenco unit, which represents a portion of the Adriatic continental margin exhumed during Jurassic rifting (Müntener et al. 2000). For the hydration of the Malenco granulites, the authors proposed an alternative scenario, consisting in the dehydration of relatively cool continental crust as consequence of juxtaposition with relatively hot granulites. Based on the oxygen isotope data, infiltration of seawater is favourable to crustal-derived fluids for the SZ. However, sea-floor alteration of basement rocks localizes along fault zones and does not pervasively affect the rocks located few tens of meters away from the faults (Manatschal et al. 2000; Müntener et al. 2000). None of the samples investigated here are located on major shear zones, but all of them are highly deformed before and during HP metamorphism. Further systematic sampling and oxygen isotope study of the EMC is necessary to provide additional insights (1) on the hypothesis of a trend in $\delta^{18} \mathrm{O}$ variation associated with the tectonic position during extension and (2) on the possibility of recognizing extensional tectonic features in the EMC and evaluate their role on the sea-floor re-hydration.

\section{Re-hydration by externally derived fluids during subduction}

Another possible setting for hydration between the preAlpine garnet and the first Alpine garnet growth is the infiltration of externally derived fluids during burial, as previously proposed by Giuntoli et al. (2018b) and Engi et al. (2018). Such fluid infiltration must have occurred before or in correspondence to Alpine garnet growth in each locality (Fig. 9). This setting is more complex and has to take into consideration potential fluid sources with low $\delta^{18} \mathrm{O}$ signature, their volume and location in the subduction channel. The variety of garnet oxygen isotopic compositions observed could be explained by a single fluid composition and different degrees of fluid-rock interaction for each sample. However, this scenario would ignore a necessary fluid evolution and demand a very large volume of fluid. In a fluid-undersaturated environment, such as in subducted continental crust, the fluid released from one rock type will evolve as it triggers metamorphic reactions in adjacent rock types. Based on this scenario, we calculated fluid/rock mass ratios (i.e. the total mass of aqueous fluid that has passed through and interacted with the rock normalized to the mass of the rock, FRR) using the strategy presented in Vho et al. (2020a).

The eclogite sample AV16-21 from Ivozio Complex has a hydrous HP assemblage and is characterized by the lowest $\delta^{18} \mathrm{O}$ values for Alpine garnet (Fig. 11). This garnet with $\delta^{18} \mathrm{O}=3.5-4.0 \%$ is expected to form in a bulk $\delta^{18} \mathrm{O}$ close to the typical gabbro signature (4-6\%o, Eiler 2001). The fluid in equilibrium with the garnet at $T=550-600{ }^{\circ} \mathrm{C}$ would have a $\delta^{18} \mathrm{O}=5-7 \%$. This is the lowest isotopic fluid composition among those in equilibrium with Alpine garnet in the studied samples. This value is referred to as pristine external fluid, to indicate the external fluid that is likely to have equilibrated the least with metasedimentary rocks before infiltrating the SZ continental basement.

Assuming that the pristine external fluid $\left(\delta^{18} \mathrm{O}=6 \%\right.$ ) pervasively infiltrated and interacted with the micaschist of Malone Valley, a FRR of $\sim 0.4$ is needed in order to decrease the initial bulk $\delta^{18} \mathrm{O}$ by $\sim 2.5 \%$. After complete equilibration with the micaschist, the fluid would have a $\delta^{18} \mathrm{O}$ of $7-10$ $\%$ (Fig. 11). Part of the infiltrating fluid might escape isotopic re-equilibration, or not reach equilibrium; therefore, this range represents the highest $\delta^{18} \mathrm{O}$ values for the fluid leaving these rocks after interaction. Such fluid that already interacted with metasediments is referred to as partially reequilibrated fluid, and would infiltrate rocks located farther away from the fluid source.

Garnet core in metaquartzite VC10-04 from Chiusella Valley constrains the initial $\delta^{18} \mathrm{O}$ bulk value to $20 \%$ o (Online Resource 4). In near absence of carbonates, this likely represents a maximum $\delta^{18} \mathrm{O}$ value for metasediments of the SZ before fluid-rock interaction. If a partially reequilibrated fluid with average $\delta^{18} \mathrm{O}$ value of $8.5 \%$ infiltrated the metaquartzite, a FRR of $\sim 0.4$ is needed to decrease the bulk $\delta^{18} \mathrm{O}$ by $\sim 4.5 \%$. This FRR value is relatively insensitive to fluid $\delta^{18} \mathrm{O}$, as infiltration of a pristine external fluid $\left(\delta^{18} \mathrm{O}=6 \%\right.$ o ) would require only a slightly lower FRR of $\sim 0.3$. Within the EMC, quartzite does not represent a widespread rock type with respect to the more common micaschists and mafic rocks (Venturini et al. 1994; Regis et al. 2015; Giuntoli and Engi 2016) and, therefore, would have a limited capacity to buffer high $\delta^{18} \mathrm{O}$ infiltrating fluids across the SZ. The calculated $\delta^{18} \mathrm{O}$ of the fluid leaving VC10-04 after complete equilibration is $13-14 \%$ and this likely lays in the upper range for the overall value of a fluid fully re-equilibrated with the typical eclogitic micaschists $\left(\delta^{18} \mathrm{O}=11-13 \%\right.$, micaschist FG1315, Fig. 11$)$. A $\delta^{18} \mathrm{O}$ of 13-14\%o represents a feasible value for an evolved fluid, i.e. a fluid in equilibrium with the typical micaschists from the SZ. This evolved fluid could have been responsible for rehydration of the Lys Valley area (Fig. 11), in agreement with what proposed by Engi et al. (2018), leading to a minimal shift of oxygen isotopic composition between the pre-Alpine garnet cores and Alpine garnet rims. 


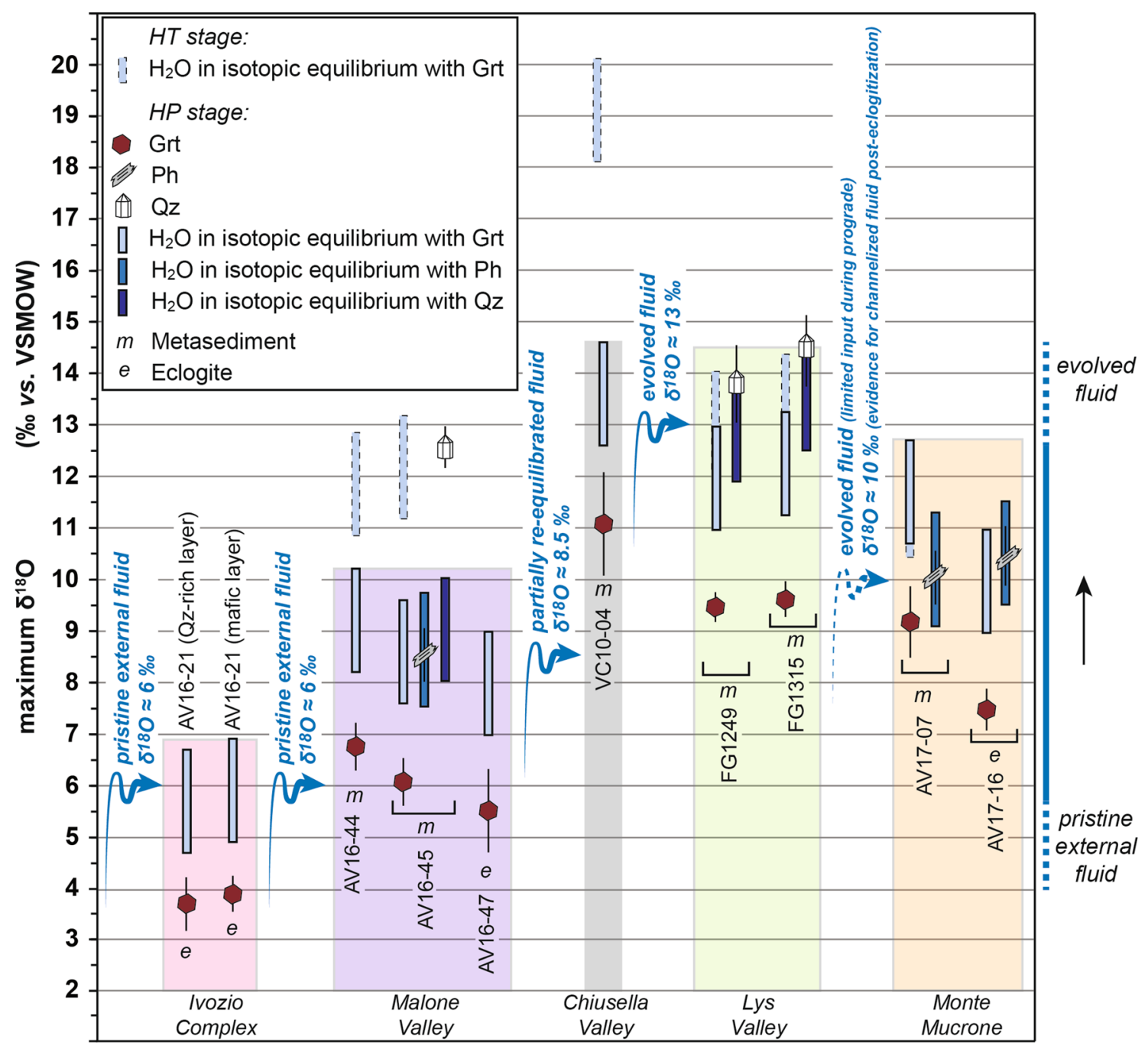

Fig. 11 Calculated $\delta^{18} \mathrm{O}$ of water in isotopic equilibrium with preAlpine garnet (Grt) cores, Alpine garnet rims, quartz (Qz) and phengite $(\mathrm{Ph})$ for all the analysed samples at temperature conditions reported in Table 1 for samples AV16-45, VC10-04, FG1249 and FG1315. For samples AV16-44 and AV16-47 the same temperature of sample AV16-45 was used; for sample AV16-21 and AV17-16 the peak temperature of $600{ }^{\circ} \mathrm{C}$ (see Table 1) was chosen; for sample AV17-07 a temperature of $700{ }^{\circ} \mathrm{C}$ was used for the pre-Alpine

Monte Mucrone is peculiar because of the abundance of preserved pre-Alpine relics (Oberhänsli et al. 1985; Zucali et al. 2002), pointing to a limited fluid-driven re-equilibration during subduction with respect to the other localities. Accordingly, no significant variation in $\delta^{18} \mathrm{O}$ was observed among different garnet zones in the micaschist. Any interaction with a fluid prior to Alpine garnet growth produced no change in the isotopic composition of the rock, suggesting that the interacting fluid had an oxygen isotope composition already in equilibrium with this rock type $\left(\delta^{18} \mathrm{O}=9-13\right.$ $\%$ o). Fluids in chemical disequilibrium seem to play a more important role in the late HP to retrograde evolution in this core and the peak temperature of $600{ }^{\circ} \mathrm{C}$ for the Alpine garnet (see Table 1). Error bars show the uncertainty on the measured $\delta^{18} \mathrm{O}$ for each mineral and of the mineral/water fractionation factors (at $2 \sigma$ ). The height of coloured fields marks the maximum $\delta^{18} \mathrm{O}$ of the water in equilibrium with HP minerals from each locality. The blue arrows represent the possible isotopic composition of the fluid infiltrating and leaving each rock slice (see text for details)

area (Konrad-Schmolke et al. 2011a; Robyr et al. 2013; Halama et al. 2014; Konrad-Schmolke and Halama 2014), producing atoll garnet textures and late phengite veins. However, the composition of the fluids in equilibrium with the two phases overlaps within the current uncertainty of the calculation.

In continental subduction zone settings, fluids with a low $\delta^{18} \mathrm{O}$ value $<7 \%$ as estimated for a pristine external fluid can derive from dehydration of rocks that previously interacted with oceanic water, such as (1) the serpentinised lithospheric mantle and (2) hydrated portions of the basement, i.e. located along extensional shear zones. The $\delta^{18} \mathrm{O}$ 
values of ultramafic rocks that underwent sea-floor alteration typically show large variations (3-9 \%o) depending on the temperature of alteration (e.g. Früh-Green et al. 1996, 2001; Philippot et al. 2007). Thus, these rock types represent a potential source for significant amount of fluid with oxygen isotope composition below $10 \%$. According to tectonic reconstructions and geochronology (e.g. Babist et al. 2006; Manzotti et al. 2014), a feasible source of water for the SZ re-hydration in the Cretaceous cannot be the subducted oceanic slab, but the partially serpentinized subcontinental mantle. In subducting ultramafic lithologies, fluid is produced by the reactions (1) antigorite + brucite $\rightarrow$ olivine + chlorite + water $\left(T \sim 500^{\circ} \mathrm{C}\right)$ and (2) antigorite $\rightarrow$ olivine + orthopyroxene + chlorite + water $\left(T \sim 650^{\circ} \mathrm{C}\right.$; Padrón-Navarta et al. 2013). The first reaction releases up to $2 \mathrm{wt} \%$ of water and it is the most likely to explain prograde hydration of the SZ rocks. If we assume a structurally coherent slice hydrated by a pristine external fluid with an average thickness of $2 \mathrm{~km}$ (Babist et al. 2006; KonradSchmolke et al. 2011a; Giuntoli and Engi 2016), considering the calculated FRR of $0.3-0.4$ and an average rock density of $3,100 \mathrm{~kg} / \mathrm{m}^{3}$ (Engi et al. 2018), $930-1,240 \mathrm{~kg}$ of water per $\mathrm{m}^{3}$ of rock are needed. This FRR is $\sim 100$ times larger than the one proposed by Konrad-Schmolke et al. (2011a) for the retrograde hydration and results in a fluid flux of $1.7 \times 10^{6}-2.2 \times 10^{6} \mathrm{~kg} / \mathrm{m}^{2}$. Considering $4 \mathrm{~km}$ of mantle peridotite with $50 \mathrm{vol} \%$ of serpentinization (as observed in the Alpine unit of Erro-Tobbio, Früh-Green et al. 2001), the total amount of water contained in a column with $1 \mathrm{~m}^{2}$ base is $\sim 6.6 \times 10^{5} \mathrm{~kg}$ of water, and $\sim 1 \times 10^{5} \mathrm{~kg}$ is expected to be released at the antigorite + brucite reaction. This is around ten times less than the amount needed for the re-hydration of the $\mathrm{SZ}$ during prograde metamorphism.

An additional source of low $\delta^{18} \mathrm{O}$ fluids would be (i) pore fluids released at shallow levels in the subduction channel by other portions of the subducting slab, or (ii) the dehydration during subduction of portions of the SZ that have been intensively re-hydrated during extension, i.e. portions located along extensional shear zones (Fig. 10). In these areas, hydrothermal alteration could have intensively recrystallized the original granulite and amphibolite facies assemblage to chlorite + illite + epidote (see above) and lowered the bulk $\delta^{18} \mathrm{O}$. During subduction, breakdown of hydrous phases within these portions could have the potential to release water in the surrounding lithologies.

Based on what is discussed above, a combination of rehydration during extension and during prograde subduction is possible and likely occurred in the SZ. Both processes caused interaction of the rocks with lower $\delta^{18} \mathrm{O}$ aqueous fluid that could have (1) driven at least part of the re-hydration, (2) generated the isotopic shifts observed between preAlpine and Alpine garnet, and (3) homogenized the oxygen isotopic composition of mafic and metasedimentary rocks at the outcrop scale. The lack of mineralogical relicts from the extensional stage and pre-HP Alpine stage makes the exact quantification of the contribution of each scenario impossible.

\section{Conclusions}

Major and trace element zoning in garnet combined with oxygen isotope investigation in garnet, quartz and phengite at the microscale were used to explore the nature of the multistage fluid-rock interaction of the Sesia Zone. Garnet elemental zoning points to a complex evolution that comprises multiple events of fluid influx that occurred both between the pre-Alpine crustal extension and the Alpine subduction, and during the Alpine burial and exhumation paths. In metasediments, garnet preserves relics of a core stable at granulite facies conditions correlated to the pre-Alpine (likely Permian) HT/LP metamorphism and one or more Alpine HP rim generations. A general trend of decreasing $\delta^{18} \mathrm{O}$ from the pre-Alpine to the Alpine garnet is observed $\left(\delta^{18} \mathrm{O}\right.$ shift of 2.9-5.3\%o), while minor to no variation occurs within the monometamorphic garnet and among different Alpine garnet generations within each sample $\left(\delta^{18} \mathrm{O}\right.$ variations $<1$ $\%$ ). This indicates that re-equilibration with an externallyderived fluid of distinct lower oxygen isotope composition occurred before, or in correspondence to, the first Alpine garnet growth. Additionally, the comparable $\delta^{18} \mathrm{O}$ of garnet from eclogites and metasediments in two localities indicates homogenization of oxygen isotopic compositions between diverse rock types at the outcrop scale. Further fluid-driven re-equilibration occurred during burial and is related to the influx of internal fluids or of external fluids with oxygen isotopic composition close to equilibrium with the rock.

Two settings, which are not mutually exclusive, are identified as possible scenarios for the observed shift in $\delta^{18} \mathrm{O}$ in the SZ samples:

(1) Partial alteration of the unit by interaction with seawater during Permo-Jurassic crustal extension. This setting is in line with evidence that some portion of the SZ were exposed at the sea floor and it can maintain a high fluid/rock ratio and a low $\delta^{18} \mathrm{O}$ of the fluid over millions of years. It however requires a widespread network of fault zones during extension, for which there is no clear evidence.

(2) Influx of serpentinite-derived fluids and/or de-hydration of previously altered portions of the Sesia Zone during Cretaceous subduction. A possible scenario is modelled in which low- $\delta{ }^{18} \mathrm{O}$ fluids percolate through the crustal rocks of the SZ during prograde Alpine subduction causing the documented changes in garnet $\delta^{18} \mathrm{O}$ and the progressive evolution of the fluid toward heavier isotopic composition. Based on equilibrium calculations, an infiltrating fluid with initial $\delta^{18} \mathrm{O}$ of $\sim 6 \%$ at a fluid/rock mass ratio of $0.3-0.4$ is needed 
to produce the observed shift in garnet $\delta^{18} \mathrm{O}$. The mass of water needed in this scenario is $930-1,240 \mathrm{~kg}$ of water per $\mathrm{m}^{3}$ of rock resulting in a fluid flux of $1.7 \times 10^{6}-2.2 \times 10^{6} \mathrm{~kg} /$ $\mathrm{m}^{2}$. Such a high mass of fluid cannot be provided even by a thick $(4 \mathrm{~km})$ layer of partly serpentinised mantle below the $\mathrm{SZ}$ and would require additional dehydration of subducted crust. Therefore, we suggest that most likely a combination of both scenarios is responsible for the observed fluid-rock interactions during subduction of the Sesia Zone.

Acknowledgements We thank Francesca Piccoli for the assistance during LA-ICP-MS analyses, Florian Bulle for helping with SIMS analysis of phengite and Anne-Sophie Bouvier for assistance during SIMS analysis. We thank Ethan Baxter and Zeb Page for their constructive comments that contributed to improve the manuscript, and the effective handling by Associate Editor Steve Reddy. We acknowledge the financial support of the Swiss National Science Foundation (grant No. 200021_166280 and 206021_170722 to Daniela Rubatto, and grant no. 200021_169062 to Jörg Hermann).

Funding Open access funding provided by University of Bern.

Open Access This article is licensed under a Creative Commons Attribution 4.0 International License, which permits use, sharing, adaptation, distribution and reproduction in any medium or format, as long as you give appropriate credit to the original author(s) and the source, provide a link to the Creative Commons licence, and indicate if changes were made. The images or other third party material in this article are included in the article's Creative Commons licence, unless indicated otherwise in a credit line to the material. If material is not included in the article's Creative Commons licence and your intended use is not permitted by statutory regulation or exceeds the permitted use, you will need to obtain permission directly from the copyright holder. To view a copy of this licence, visit http://creativecommons.org/licenses/by/4.0/.

\section{References}

Ague JJ (2003) Fluid infiltration and transport of major, minor, and trace elements during regional metamorphism of carbonate rocks, Wepawaug Schist, Connecticut, USA. Am J Sci 303:753-816

Babist J, Handy MR, Konrad-Schmolke M, Hammerschmidt K (2006) Precollisional, multistage exhumation of subducted continental crust: The Sesia Zone, western Alps. Tectonics 25: TC6008

Baumgartner LP, Valley JW (2001) Stable isotope transport and contact metamorphic fluid flow. Rev Mineral Geochem 43:415-467

Baxter E, Caddick M, Dragovic B (2017) Garnet: A rock-forming mineral petrochronometer. Rev Mineral Geochem 83(1):469-533

Beinlich A, Klemd R, John T, Gao J (2010) Trace-element mobilization during Ca-metasomatism along a major fluid conduit: Eclogitization of blueschist as a consequence of fluid-rock interaction. Geochim Cosmochim Acta 74:1892-1922

Caddick MJ, Kohn MJ (2013) Garnet: witness to the evolution of destructive plate boundaries. Elements 9:427-432

Cenki-Tok B, Oliot E, Rubatto D et al (2011) Preservation of Permian allanite within an Alpine eclogite facies shear zone at Mt Mucrone, Italy: Mechanical and chemical behavior of allanite during mylonitization. Lithos 125:40-50

Chakraborty S, Ganguly J (1991) Compositional zoning and cation diffusion in garnets. In: Diffusion, Atomic Ordering, and Mass Transport. Springer, pp 120-175
Compagnoni R (1977) The Sesia-Lanzo Zone: high pressure-low temperature metamorphism in the Austroalpine continental margin. Rendiconti della Societa Italiana di Mineralogia e Petrologia 33:335-378

Corti L, Zucali M, Visalli R et al (2019) Integrating X-ray computed tomography with chemical imaging to quantify mineral recrystallization from granulite to eclogite metamorphism in the Western Italian Alps (Sesia-Lanzo Zone). Front Earth Sci 7:327

Dal Piaz GV (1972) La Zona Sesia-Lanzo e l'evoluzione tettonicometamorfica delle Alpi nordoccidentali interne. Memoirs of the Geological Society of Italy 11:433-460

Dal Piaz G, Cortiana G, Del Moro A et al (2001) Tertiary age and paleostructural inferences of the eclogitic imprint in the Austroalpine outliers and Zermatt-Saas ophiolite, western Alps. Int J Earth Sci 90:668-684

Delleani F, Spalla MI, Castelli D, Gosso G (2012) Multiscale structural analysis in the subducted continental crust of the internal Sesia-Lanzo Zone (Monte Mucrone, Western Alps). J Virtual Explorer 41:1-35

Delleani F, Rebay G, Zucali M et al (2018) Insights on Variscan geodynamics from the structural and geochemical characterization of a Devonian-Carboniferous gabbro from the Austroalpine Domain (Western Alps). Ofioliti 43:23-39

Eiler JM (2001) Oxygen isotope variations of basaltic lavas and upper mantle rocks. Rev Mineral Geochem 43:319-364

Engi M, Giuntoli F, Lanari P et al (2018) Pervasive Eclogitization due to brittle deformation and rehydration of subducted basement: effects on continental recycling? Geochem Geophys Geosyst 19:865-881

Erambert M, Austrheim H, akon, (1993) The effect of fluid and deformation on zoning and inclusion patterns in poly-metamorphic garnets. Contrib Miner Petrol 115:204-214

Ferraris C, Compagnoni R (2003) Metamorphic evolution and significance of a serpentinized peridotite slice within the Eclogitic Micaschist Complex of the Sesia-Zone (Western Alps-Italy). Swiss Bull Mineral Petrol 83:3-13

Früh-Green GL, Weissert H, Bernoulli D (1990) A multiple fluid history recorded in Alpine ophiolites. J Geol Soc 147:959-970

Früh-Green GL, Plas A, Lécuyer C (1996) 14. Petrologic and stable isotope constraints on hydrothermal alteration and serpentinization of the EPR shallow mantle at Hess Deep (site 895). In: Proceedings of the Ocean Drilling Program, Scientific Results. pp 255-291

Früh-Green GL, Scambelluri M, Vallis F (2001) O-H isotope ratios of high pressure ultramafic rocks: implications for fluid sources and mobility in the subducted hydrous mantle. Contrib Miner Petrol 141:145-159

García-Casco A, Torres-Roldán RL, Millán G et al (2002) Oscillatory zoning in eclogitic garnet and amphibole, Northern Serpentinite Melange, Cuba: a record of tectonic instability during subduction? J Metamorph Geol 20:581-598

George FR, Gaidies F, Boucher B (2018) Population-wide garnet growth zoning revealed by LA-ICP-MS mapping: implications for trace element equilibration and syn-kinematic deformation during crystallisation. Contrib Miner Petrol 173:74

Gerrits AR, Inglis EC, Dragovic B, Starr PG, Baxter EF, Burton KW (2019) Release of oxidizing fluids in subduction zones recorded by iron isotope zonation in garnet. Nat Geosci 12:1029-1033

Giuntoli F, Engi M (2016) Internal geometry of the central Sesia Zone (Aosta Valley, Italy): HP tectonic assembly of continental slices. Swiss J Geosci 109:445-471

Giuntoli F, Lanari P, Burn M et al (2018) Deeply subducted continental fragments-Part 2: Insight from petrochronology in the central Sesia Zone (western Italian Alps). Solid Earth 9:191-222

Giuntoli F, Lanari P, Engi M (2018) Deeply subducted continental fragments-Part 1: fracturing, dissolution-precipitation, and diffusion 
processes recorded by garnet textures of the central Sesia Zone (western Italian Alps). Solid Earth 9:167-167

Gosso G (1977) Metamorphic evolution and fold history in the eclogitic micaschists of the Upper Gressoney Valley (Sesia-Lanzo Zone, Western Alps). Rendiconti della Societa Italiana di Mineralogia e Petrologia 33:389-407

Guillong M, Meier DL, Allan MM et al (2008) Appendix A6: SILLS: A MATLAB-based program for the reduction of laser ablation ICP-MS data of homogeneous materials and inclusions. Mineral Assoc Can Short Course 40:328-333

Halama R, Konrad-Schmolke M, Sudo M et al (2014) Effects of fluidrock interaction on 40Ar/39Ar geochronology in high-pressure rocks (Sesia-Lanzo Zone, Western Alps). Geochim Cosmochim Acta 126:475-494

Hellstrom J, Paton C, Woodhead J, Hergt J (2008) Iolite: software for spatially resolved LA-(quad and MC) ICPMS analysis. Mineral Assoc Can Short Course Ser 40:343-348

Hermann J (2002) Experimental constraints on phase relations in subducted continental crust. Contrib Miner Petrol 143:219-235

Hermann J, Rubatto D (2009) Accessory phase control on the trace element signature of sediment melts in subduction zones. Chem Geol 265:512-526

Hermann J, Spandler C, Hack A, Korsakov AV (2006) Aqueous fluids and hydrous melts in high-pressure and ultra-high pressure rocks: implications for element transfer in subduction zones. Lithos 92:399-417

Hermann J, Zheng Y-F, Rubatto D (2013) Deep fluids in subducted continental crust. Elements 9:281-287

Incerpi N, Martire L, Manatschal G, Bernasconi SM (2017) Evidence of hydrothermal fluid flow in a hyperextended rifted margin: the case study of the Err nappe (SE Switzerland). Swiss J Geosci 110:439-456

Jamtveit B, Austrheim H (2010) Metamorphism: the role of fluids. Elements 6:153-158

Jarrard RD (2003) Subduction fluxes of water, carbon dioxide, chlorine, and potassium. Geochem Geophys Geosyst 4:5

Jochum KP, Nohl U, Herwig K et al (2005) GeoReM: a new geochemical database for reference materials and isotopic standards. Geostand Geoanal Res 29:333-338

Jochum KP, Weis U, Stoll B et al (2011) Determination of reference values for NIST SRM 610-617 glasses following ISO guidelines. Geostand Geoanal Res 35:397-429

Kohn MJ (1993) Modeling of prograde mineral $\delta 180$ changes in metamorphic systems. Contrib Miner Petrol 113:249-261

Konrad-Schmolke M, Halama R (2014) Combined thermodynamicgeochemical modeling in metamorphic geology: boron as tracer of fluid-rock interaction. Lithos 208:393-414

Konrad-Schmolke M, Babist J, Handy MR, O'brien PJ (2006) The physico-chemical properties of a subducted slab from garnet zonation patterns (Sesia Zone, Western Alps). J Petrol 47:2123-2148

Konrad-Schmolke M, O’Brien PJ, Heidelbach F (2007) Compositional re-equilibration of garnet: the importance of sub-grain boundaries. Eur J Mineral 19:431-438

Konrad-Schmolke M, O'Brien PJ, Zack T (2011a) Fluid migration above a subducted slab - constraints on amount, pathways and major element mobility from partially overprinted eclogite-facies rocks (Sesia Zone, Western Alps). J Petrol 52:457-486

Konrad-Schmolke M, Zack T, O'Brien PJ, Barth M (2011b) Fluid migration above a subducted slab-Thermodynamic and trace element modelling of fluid-rock interaction in partially overprinted eclogite-facies rocks (Sesia Zone, Western Alps). Earth Planet Sci Lett 311:287-298
Kunz BE, Manzotti P, von Niederhäusern B et al (2018) Permian hightemperature metamorphism in the Western Alps (NW Italy). Int J Earth Sci 107:203-229

Kurz W, Neubauer F, Dachs E (1998) Eclogite meso-and microfabrics: implications for the burial and exhumation history of eclogites in the Tauern Window (Eastern Alps) from PTd paths. Tectonophysics 285:183-209

Lanari P, Engi M (2017) Local bulk composition effects on metamorphic mineral assemblages. Rev Mineral Geochem 83:55-102

Lanari P, Vidal O, De Andrade V et al (2014) XMapTools: A MATLAB (-based program for electron microprobe X-ray image processing and geothermobarometry. Comput Geosci 62:227-240

Lanari P, Giuntoli F, Loury C et al (2017) An inverse modeling approach to obtain P-T conditions of metamorphic stages involving garnet growth and resorption. Eur J Mineral 29:181-199

Lanari P, Vho A, Bovay T et al (2019) Quantitative compositional mapping of mineral phases by electron probe micro-analyser. Geol Soc Lond Spec Publ 478:39-63

Lardeaux JM, Spalla MI (1991) From granulites to eclogites in the Sesia zone (Italian Western Alps): a record of the opening and closure of the Piedmont ocean. J Metamorph Geol 9:35-59

Lardeaux J-M, Gosso G, Kienast JR, Lombardo B (1982) Relations entre le metamorphisme et la deformation dans la zone SesiaLanzo (Alpes Occidentales) et le probleme de l'eclogitisation de la croute continentale. Bulletin de la Société géologique de France 7:793-800

Manatschal G, Marquer D, Früh-Green GL (2000) Channelized fluid flow and mass transfer along a rift-related detachment fault (Eastern Alps, southeast Switzerland). Geol Soc Am Bull 112:21-33

Manning CE (2004) The chemistry of subduction-zone fluids. Earth Planet Sci Lett 223:1-16

Manzotti P, Ballevre M, Zucali M et al (2014) The tectonometamorphic evolution of the Sesia-Dent Blanche nappes (internal Western Alps): review and synthesis. Swiss J Geosci 107:309-336

Martin LAJ, Ballevre M, Boulvais P et al (2011) Garnet re-equilibration by coupled dissolution-reprecipitation: evidence from textural, major element and oxygen isotope zoning of 'cloudy'garnet. J Metamorph Geol 29:213-231

Martin LA, Rubatto D, Crépisson C et al (2014) Garnet oxygen analysis by SHRIMP-SI: Matrix corrections and application to highpressure metasomatic rocks from Alpine Corsica. Chem Geol 374:25-36

Martin LAJ, Hermann J, Gauthiez-Putallaz L et al (2014) Lawsonite geochemistry and stability-implication for trace element and water cycles in subduction zones. J Metamorph Geol 32:455-478

Moore SJ, Carlson WD, Hesse MA (2013) Origins of yttrium and rare earth element distributions in metamorphic garnet. J Metamorph Geol 31:663-689

Müntener O, Hermann J, Trommsdorff V (2000) Cooling history and exhumation of lower-crustal granulite and upper mantle (Malenco, Eastern Central Alps). J Petrol 41:175-200

Oberhänsli R, Hunziker JC, Martinotti G, Stern WB (1985) Geochemistry, geochronology and petrology of Monte Mucrone: an example of Eo-Alpine eclogitization of Permian granitoids in the Sesia-Lanzo Zone, Western Alps, Italy. Chem Geol 52:165-184

Otamendi JE, de La Rosa JD, Douce AEP, Castro A (2002) Rayleigh fractionation of heavy rare earths and yttrium during metamorphic garnet growth. Geology 30:159-162

Padrón-Navarta JA, Sánchez-Vizcaíno VL, Hermann J et al (2013) Tschermak's substitution in antigorite and consequences for phase relations and water liberation in high-grade serpentinites. Lithos 178:186-196 
Page FZ, Kita NT, Valley JW (2010) Ion microprobe analysis of oxygen isotopes in garnets of complex chemistry. Chem Geol 270:9-19

Parsons I, Lee MR (2009) Mutual replacement reactions in alkali feldspars I: microtextures and mechanisms. Contrib Miner Petrol 157:641

Paton C, Hellstrom J, Paul B et al (2011) Iolite: Freeware for the visualisation and processing of mass spectrometric data. J Anal At Spectrom 26:2508-2518

Philippot P, Busigny V, Scambelluri M, Cartigny P (2007) Oxygen and nitrogen isotopes as tracers of fluid activities in serpentinites and metasediments during subduction. Mineral Petrol 91:11-24

Piccoli F, Brovarone AV, Ague JJ (2018) Field and petrological study of metasomatism and high-pressure carbonation from lawsonite eclogite-facies terrains, Alpine Corsica. Lithos 304:16-37

Pinto VHG, Manatschal G, Karpoff AM, Viana A (2015) Tracing mantle-reacted fluids in magma-poor rifted margins: The example of Alpine Tethyan rifted margins. Geochem Geophys Geosyst 16:3271-3308

Pognante U (1989a) Lawsonite, blueschist and eclogite formation in the southern Sesia Zone (Western Alps, Italy). Eur J Min 10:89-104

Pognante U (1989b) Tectonic implications of lawsonite formation in the Sesia zone (Western Alps). Tectonophysics 162:219-227

Pognante U (1991) Petrological constraints on the eclogite-and blueschistfacies metamorphism and P-T-t paths in the western Alps. J Metamorph Geol 9:5-17

Pognante U, Compagnoni R, Gosso G (1980) Micro-mesostructural relationships in the continental eclogitic rocks of the Sesia-Lanzo Zone (Italian Western Alps): a record of a subduction cycle. Rend Soc Ital Mineral Petrol 36:169-186

Poli S, Schmidt MW (2002) Petrology of subducted slabs. Annu Rev Earth Planet Sci 30:207-235

Putnis A (2009) Mineral replacement reactions. Rev Mineral Geochem 70:87-124

Putnis A, Austrheim H (2010) Fluid-induced processes: metasomatism and metamorphism. Geofluids 10:254-269

Rebay G, Messiga B (2007) Prograde metamorphic evolution and development of chloritoid-bearing eclogitic assemblages in subcontinental metagabbro (Sesia-Lanzo zone, Italy). Lithos 98:275-291

Rebay G, Spalla MI (2001) Emplacement at granulite facies conditions of the Sesia-Lanzo metagabbros: an early record of Permian rifting? Lithos 58:85-104

Regis D, Rubatto D, Darling J et al (2014) Multiple metamorphic stages within an eclogite-facies terrane (Sesia Zone, Western Alps) revealed by Th-U-Pb petrochronology. J Petrol 55:1429-1456

Regis D, Venturini G, Engi M (2015) Geology of the Scalaro valleySesia Zone (Italian Western Alps). J Maps 12:621-629

Robyr M, Darbellay B, Baumgartner LP (2013) Matrix-dependent garnet growth in polymetamorphic rocks of the Sesia zone, Italian Alps. J Metamorph Geol 32:3-24

Rubatto D (1998) Dating of pre-Alpine magmatism, Jurassic ophiolites and Alpine subductions in the Western Alps. PhD thesis, Swiss Federal Institute of Technology Zürich

Rubatto D (2002) Zircon trace element geochemistry: partitioning with garnet and the link between $\mathrm{U}-\mathrm{Pb}$ ages and metamorphism. Chem Geol 184:123-138

Rubatto D, Angiboust S (2015) Oxygen isotope record of oceanic and high-pressure metasomatism: a P-T-time-fluid path for the Monviso eclogites (Italy). Contrib Miner Petrol 170:44

Rubatto D, Gebauer D, Compagnoni R (1999) Dating of eclogite-facies zircons: the age of Alpine metamorphism in the Sesia-Lanzo Zone (Western Alps). Earth Planet Sci Lett 167:141-158

Rubatto D, Regis D, Hermann J et al (2011) Yo-yo subduction recorded by accessory minerals in the Italian Western Alps. Nat Geosci $4: 338$
Rubatto D, Burger M, Lanari P et al (2020) Identification of growth mechanisms in metamorphic garnet by high-resolution trace element mapping with LA-ICP-TOFMS. Contrib Miner Petrol 175:61. https://doi.org/10.1007/s00410-020-01700-5

Scambelluri M, Philippot P (2001) Deep fluids in subduction zones. Lithos 55:213-227

Schumacher R, Rötzler K, Maresch WV (1999) Subtle oscillatory zoning in garnet from regional metamorphic phyllites and mica schists, western Erzgebirge, Germany. Can Mineral 37:381-403

Seitz S, Baumgartner LP, Bouvier A-S, Putlitz B, Vennemann T (2017) Quartz reference materials for oxygen isotope analysis by SIMS. Geostand Geoanal Res 41:69-75. https://doi.org/10.1111/ ggr.12133

Spandler C, Pirard C (2013) Element recycling from subducting slabs to arc crust: A review. Lithos 170:208-223

Spear FS (1995) Metamorphic phase equilibria and pressure-temperature-time paths. Mineralogical Society of America, Washington, D.C.

Spear FS, Kohn MJ (1996) Trace element zoning in garnet as a monitor of crustal melting. Geology 24:1099-1102

Tropper P, Essene EJ (1999) Application of K-feldspar-jadeite-quartz barometry to eclogite facies metagranites and metapelites in the Sesia Lanzo Zone (Western Alps, Italy). J Metamorph Geol 17:195-209

Valley JW, Kitchen N, Kohn MJ et al (1995) UWG-2, a garnet standard for oxygen isotope ratios: strategies for high precision and accuracy with laser heating. Geochim Cosmochim Acta 59:5223-5231

Venturini G, Martinotti G, Armando G et al (1994) The central SesiaLanzo zone (Western Italian Alps)-New field observations and lithostratigraphic subdivisions. Schweiz Mineral Petrogr Mitt $74: 115-125$

Vho A, Lanari P, Rubatto D (2019) An internally-consistent database for oxygen isotope fractionation between minerals. J Petrol 60:2101-2130

Vho A, Lanari P, Rubatto D, Hermann J (2020) Tracing fluid transfers in subduction zones: an integrated thermodynamic and $\delta^{18} \mathrm{O}$ fractionation modelling approach. Solid Earth 11:1-22

Vho A, Rubatto D, Putlitz B, Bouvier A-S (2020) New reference materials and assessment of matrix effects for SIMS measurements of oxygen isotopes in garnet. Geostand Geoanal Res. https://doi. org/10.1111/ggr.12324

Vielzeuf D, Veschambre M, Brunet F (2005) Oxygen isotope heterogeneities and diffusion profile in composite metamorphic-magmatic garnets from the Pyrenees. Am Miner 90:463-472

Vitale Brovarone A, Beyssac O (2014) Lawsonite metasomatism: a new route for water to the deep Earth. Earth Planet Sci Lett 393:275-284

Vitale Brovarone A, Alard O, Beyssac O et al (2014) Lawsonite metasomatism and trace element recycling in subduction zones. J Metamorph Geol 32:489-514

Vitale Brovarone A, Chu X, Martin L et al (2018) Intra-slab COH fluid fluxes evidenced by fluid-mediated decarbonation of lawsonite eclogite-facies altered oceanic metabasalts. Lithos 304:211-229

Whitney DL, Evans BW (2010) Abbreviations for names of rock-forming minerals. Am Miner 95:185-187

Yardley BW, Valley JW (1997) The petrologic case for a dry lower crust. J Geophys Res 102:12173-12185

Zack T, Foley SF, Rivers T (2002) Equilibrium and disequilibrium trace element partitioning in hydrous eclogites (Trescolmen, Central Alps). J Petrol 43:1947-1974

Zucali M (2002) Structural map of the "Eclogitic micaschists complex" (Monte Mucrone-Monte Mars-Mombarone. Università degli Studi di Milano, Sesia-Lanzo zone

Zucali M, Spalla MI (2011) Prograde lawsonite during the flow of continental crust in the Alpine subduction: Strain vs. metamorphism 
partitioning, a field-analysis approach to infer tectonometamorphic evolutions (Sesia-Lanzo Zone, Western Italian Alps). J Struct Geol 33:381-398

Zucali M, Spalla MI, Gosso G (2002) Strain partitioning and fabric evolution as a correlation tool: the example of the Eclogitic Micaschists Complex in the Sesia-Lanzo Zone (Monte MucroneMonte Mars, Western Alps, Italy). Schweiz Mineral Petrogr Mitt $82: 429-454$
Zucali M, Spalla MI, Gosso G et al (2004) Prograde LWS-KY transition during subduction of the Alpine continental crust of the Sesia-Lanzo Zone: The Ivozio Complex. J Virtual Explorer 16:1-21

Publisher's Note Springer Nature remains neutral with regard to jurisdictional claims in published maps and institutional affiliations. 